\title{
Electrochemical Detection and Point-of-Care Testing for Circulating Tumor Cells: Current Techniques and Future Potentials
}

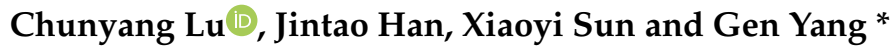 \\ State Key Laboratory of Nuclear Physics and Technology, School of Physics, Peking University, Beijing 100871, \\ China; 1701110253@pku.edu.cn (C.L.); 1801110241@pku.edu.cn (J.H.); 1901110259@pku.edu.cn (X.S.) \\ * Correspondence: gen.yang@pku.edu.cn
}

Received: 30 September 2020; Accepted: 23 October 2020; Published: 26 October 2020

\begin{abstract}
Circulating tumor cells (CTCs) are tumor cells that escaped from the primary tumor or the metastasis into the blood and they play a major role in the initiation of metastasis and tumor recurrence. Thus, it is widely accepted that CTC is the main target of liquid biopsy. In the past few decades, the separation of CTC based on the electrochemical method has attracted widespread attention due to its convenience, rapidness, low cost, high sensitivity, and no need for complex instruments and equipment. At present, CTC detection is not widely used in the clinic due to various reasons. Point-of-care CTC detection provides us with a possibility, which is sensitive, fast, cheap, and easy to operate. More importantly, the testing instrument is small and portable, and the testing does not require specialized laboratories and specialized clinical examiners. In this review, we summarized the latest developments in the electrochemical-based CTC detection and point-of-care CTC detection, and discussed the challenges and possible trends.
\end{abstract}

Keywords: circulating tumor cells; electrochemical detection; point-of-care testing

\section{Introduction}

Cancer is one of the leading causes of death, and around $90 \%$ cancer death due to metastasis [1,2]. Therefore, achieving an earlier cancer diagnosis is of fundamental importance. For conventional needle biopsy techniques, the invasiveness limits its use. Meanwhile, liquid biopsy techniques analyze tumor cells or tumor cell debris from blood or other body fluids, including circulating tumor cells (CTCs), circulating tumor DNA (ctDNA), extracellular vesicles (EVs), and exosomes, etc. [3]. Compared with needle biopsy, its non-invasiveness allows us to collect patient blood samples continuously, and to realize real-time monitoring of patient disease progression and personalized medicine [4,5]. Moreover, since CTC, ctDNA, EVs, etc. can be released from both primary and metastatic tumors, liquid biopsy provides us more comprehensive information [6,7]. CTC is the main target of liquid biopsy, for CTC is the most important part during the metastasis process [8]. It has been reported that CTC could be detected before cancer forms metastasis $[9,10]$. Detection of CTC in the blood could be used to achieve an earlier diagnosis and a better control of cancer, and avoid the bad consequences caused by cancer metastasis. Besides, CTC could be used to assess the patient prognosis and evaluate the treatment outcome in real-time [5,11]. The isolation, culture, and sequencing of CTC could also help us to determine patients' drug resistance and find potential therapeutic targets [12-15].

Separating CTC from complex blood components is extremely challenging. The amount of CTC in the blood is extremely rare, in average about $1-100 \mathrm{~mL}^{-1}$ [16], while the number of white blood cells $(\mathrm{WBC})$ and red blood cells $(\mathrm{RBC})$ is about $0.4-1 \times 10^{7} \mathrm{~mL}^{-1}$ and $3.5-5 \times 10^{9} \mathrm{~mL}^{-1}$, respectively. The separation mainly relies on the difference in biological properties or physical properties between 
CTC and blood cells [17]. Biological properties-based CTC separation, mainly using the unique antigen expression on the surface of CTC, such as the most commonly used anti-epithelial cell adhesion molecule (EpCAM) and Cytokeratin (CK), etc. [18]. Coupling these antibodies to the surface of magnetic beads or the chip can achieve the specific capture and separation of CTC. Physical properties-based CTC separation mainly uses the difference in cell density, size, and deformability between CTC and blood cells to achieve CTC separation [19-21]. Although there are many CTC detection methods, their complicated operation process, high cost, and low sensitivity are still problems. In recent years, a lot of electrochemical methods have also been used to detect CTC, using aptamers and nanomaterials to modify the electrode, by recording the current change/electrical impedance spectrum change, and establishing a linear relationship between the change and the number of CTC to realize the quantification of CTC [22,23]. This ensures high sensitivity and selectivity, and has outstanding advantages, such as rapid response, easy operation, affordability, and nondestructive analysis [22].

After completing the separation of CTC, it is very important to quantify the number of CTC. In general, traditional biological properties-based methods and physical properties-based methods use fluorescently labeled antibodies to identify and count the captured CTCs. CTCs were recognized as Hoechst+ (nuclear dye), EpCAM+/CK+, and CD45- (WBC specific marker) cells, while WBCs were recognized as Hoechst+, EpCAM-/CK-, and CD45+ cells [24-26]. This fluorescence imaging-based method usually requires a specialized fluorescence microscope, which is expensive, and the output of the results requires professional technicians and also takes a long time, thus limiting its clinical use. The electrochemical-based method only requires some simple instruments, such as current meters, and the whole detection process is relatively simple and fast [27-30]. However, the preparation process of the device is complicated and the detection time is long. There is an urgent need for a simpler, more efficient, and faster method. Point-of-care testing (POCT) realizes target quantification through pressure, distance, color, etc. As a sensitive, fast, cheap, easy-to-operate method, it allows patients to realize sample input and result output, and it doesn't need for complex equipment [31,32]. The test can be performed at the bedside of the patient and the results are available immediately. It is of great significance for popularizing the clinical application of CTC detection.

This review first briefly introduced biological properties-based and physical properties-based CTC detection methods, and then summarized the latest progress in the electrochemical detection of CTC. Further, we discussed advantages and disadvantages in the electrochemical detection of CTC and proposed possible development directions. Then, we introduced POCT and showed some examples. Finally, we discussed some possible combinations of POCT and CTC detection.

\section{CTC Separation Methods Based on Biological Properties and Physical Properties}

Various CTC enrichment technologies have been developed, which can be roughly divided into two categories, namely biological properties-based methods and physical properties-based methods. These methods usually combined with the microfluidic chip, the reason is that the microfluidic chip usually integrates various functions, including preprocessing, mixing, separation, detection, and so on. By reasonably designing channels, columns and chambers, cells could be separated well. In addition, it achieved high-throughput detection, hundreds of samples can be analyzed within a few minutes. The most important thing is that the microfluidic chip requires less reagent consumption, the cost is low, and it's easy to operate [33]. We summarized the biological properties-based methods and physical properties-based methods in Table 1, and their application flow rate, capture efficiency, and purity were listed. 


\subsection{Methods Based on Biological Properties}

Tumor metastasis includes four processes. (1) Invasion: tumor cells undergo epithelial-mesenchymal transition (EMT), which promotes the downregulation of adhesion between cells, and cells fall off from the primary tumor, obtain high mobility and invasiveness at the same time. (2) Intravasation: tumor cells pass through basement membrane (BM) and enter the blood vessels or lymph vessels, also called circulating tumor cells (CTC, including single CTC and CTC cluster). Only a very small number of CTCs can survive and form metastases. The reason for this is that CTCs are exposed to high shear stress in the blood and are attacked by immune cells [34]. They undergo apoptosis and are quickly eliminated. In addition, because the tumor cells leave the extracellular matrix (ECM), anoikis will occur [35]. Overall, CTCs have a short half-life in blood (1.0-2.4 h in patients with breast cancer) [36]. (3) Extravasation: when the CTC reaches the distal capillaries (diameter: 6-9 $\mu \mathrm{m}$ ), it may get stuck and get out of the blood or lymphatic vessels. This process relies on neutrophils to release matrix metalloproteinases (MMPs) to weaken the connection between endothelial cells. (4) Metastases: tumor cells may remain in dormant state for a period of time, when the external environment is suitable for proliferation, they may undergo mesenchymal-epithelial transition (MET), which allows cells to restore high adhesion properties, promoting them to establish connections, and finally form metastasis (Figure 1A) [10,37]. From the above description, we know that CTC plays an important part in the metastasis process. For different cancer types, CTC markers are slightly different. For example, in breast cancer, the commonly used markers are CK19, EpCAM and hMAM [38]; in lung cancer, the markers are CK7, CK19, and TTF-1 [39,40]; in prostate cancer, the markers are PSA and PSMA [41]; in colorectal cancer, the markers are CK and CD133 [42,43]; in pancreatic cancer, the markers are CK19, EpCAM, and MUC1 [43]; in ovarian cancer, the markers are EpCAM and MUC1 [44]. We showed the typical fluorescence image and SEM image of CTC (Figure 1B,C).

Biological properties-based CTC separation, usually using the unique CTC molecular markers, the most frequently used are EpCAM and CK, they are not expressed on blood cells. CellSearch ${ }^{\mathrm{TM}}$ is the only platform approved by the FDA for commercial detection of CTCs. CTCs are combined with EpCAM-coated magnetic beads and then separated under the magnetic field. After fluorescent labeling, CTC is defined as Hoechst+, EpCAM+/CK+ and CD45- (Figure 2) [45,46]. Such magnetically activated cell sorting is called positive sorting $[47,48]$. Moreover, antibody-coated magnetic beads can also be bounded to the background cells, for example, using CD45 labeled magnetic beads to identify and remove WBCs, this kind of cell sorting is called negative sorting [49]. After that, researchers introduced this principle to microfluidic chips, and achieved the capture of CTC by coupling antibodies to the surface of the chip [24,25]. Some researchers have modified the surface of the chip with nanomaterials or surfactant/lipid bilayers, etc. [50] to promote the interaction between CTC and antibody and reduce non-specific cell adsorption [51], and effectively increase the CTC capture efficiency as well as reduce the contamination rate (Figure 2).

Biological properties-based CTC separation method usually has high purity due to the specific interaction between antigen and antibody, but its operation processes including labeling and sorting are complicated, the throughput is low (usually between 1-3 $\mathrm{mL} \mathrm{h}^{-1}$ ), and due to a large amount of antibody is consumed, the cost is high (Table 1). More importantly, due to the EMT of CTCs during metastasis, not all cancer cells express E-type markers [37,52,53], which causes the loss and underestimation of the number of CTCs. 


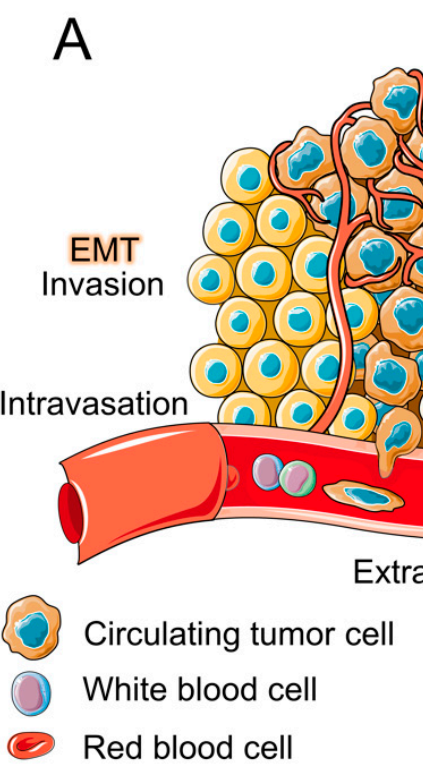
Metastasis

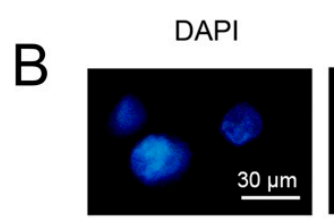

EpCAM/CK

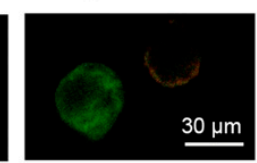

CD45

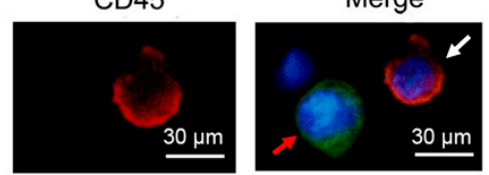

C

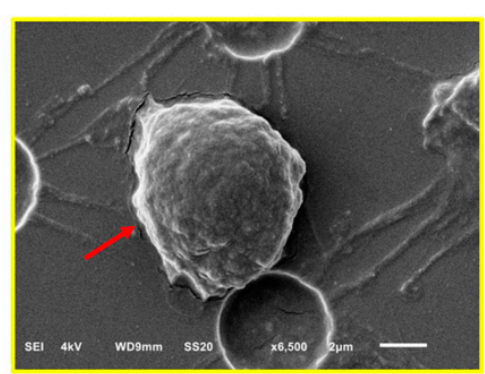

Figure 1. The biological properties of CTC. (A) A schematic diagram of the four stages of tumor metastasis formation, which is invasion, intravasation, extravasation and metastasis. (B) Fluorescence image of CTC (red arrow) and WBC (white arrow), cells were stained with DAPI, EpCAM/CK and CD45 $($ Scale bars $=30 \mu \mathrm{m})$ [54]. (C) Scanning electron micrograph of CTC (red arrow) (Scale bar $=2 \mu \mathrm{m})$ [55].

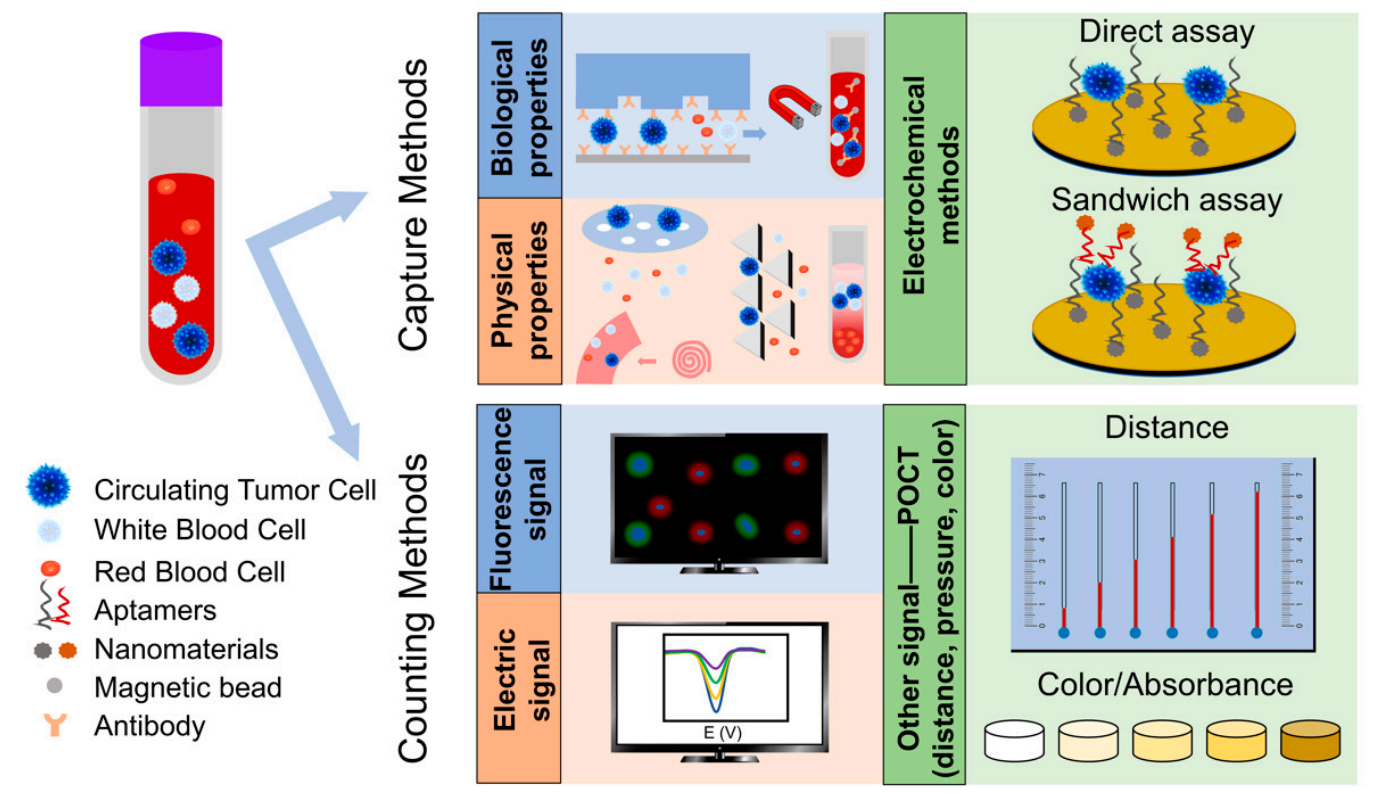

Figure 2. The capture methods and counting methods of CTC. The capture methods including biological properties-based methods, physical properties-based methods and electrochemical methods. The counting methods including fluorescence signal-based methods, electric signal-based methods and other signal-based methods (simple signal, such as distance, pressure and color etc.). 
Table 1. Summary of biological and physical properties-based CTC detection methods.

\begin{tabular}{|c|c|c|c|c|c|c|c|c|}
\hline $\begin{array}{l}\text { Separation } \\
\text { Principles }\end{array}$ & Technology & $\begin{array}{c}\text { Flow } \\
\text { Rate } \\
\left(\mathrm{mL} \mathrm{h}^{-1}\right)\end{array}$ & $\begin{array}{l}\text { Effective } \\
\text { Flow Rate } \\
\left(\mathrm{mL} \mathrm{h}^{-1}\right)\end{array}$ & Efficiency/Sensitivity & Capture Purity & $\begin{array}{l}\text { Enrichment } \\
\quad \text { Factor }\end{array}$ & Clinical Sample & Ref. \\
\hline \multirow{5}{*}{$\begin{array}{c}\text { Biological } \\
\text { properties-based } \\
\text { methods }\end{array}$} & CellSearch & 3 & 3 & $80-82 \%$ & - & - & $\begin{array}{c}\text { Metastatic breast, prostate } \\
\text { or colorectal }\end{array}$ & [56] \\
\hline & CTC-chip & $1-2$ & $1-2$ & $>60 \%$ & $49-67 \%$ & - & $\begin{array}{l}\text { Non small cell lung cancer } \\
(n=55), \text { prostate }(n=26), \\
\text { pancreatic }(n=15), \text { breast } \\
(n=10) \text { and colon }(n=10)\end{array}$ & [24] \\
\hline & HB-chip & 1.2 & 1.2 & $91.8 \pm 5.2 \%$ & $14.0 \pm 0.1 \%$ & - & $\begin{array}{l}\text { Prostate }(\mathrm{n}=15) \text {, lung } \\
(\mathrm{n}=4)\end{array}$ & [25] \\
\hline & CellCollector & 30 & 30 & $10-35 \%$ & $50-96.4 \%$ & - & Pancreatic $(n=43)$ & [57] \\
\hline & GO-chip & $1-3$ & $1-3$ & $84-95 \%$ & - & - & $\begin{array}{c}\text { Breast }(\mathrm{n}=10) \text {, pancreatic } \\
\qquad(\mathrm{n}=3)\end{array}$ & [58] \\
\hline \multirow{5}{*}{$\begin{array}{l}\text { Physical } \\
\text { properties-based } \\
\text { methods }\end{array}$} & DLD & 600 & 30 & $85 \%$ & - & 3.4 & - & [59] \\
\hline & Vortex-chip & $240-360$ & 12 & $20.7 \%$ & $89 \%$ & $3.5 \times 10^{4}$ & Breast $(\mathrm{n}=4)$, lung $(\mathrm{n}=8)$ & [60] \\
\hline & $\begin{array}{l}\text { Multiplexed } \\
\text { spiral chip }\end{array}$ & 21 & 21 & $76.4-87.6 \%$ & 1CTC/30-100WBCs & $\sim 10^{4}$ & Breast $(n=5)$, lung $(n=5)$ & [61] \\
\hline & Labyrinth-chip & 150 & 30 & $>90 \%$ & $\begin{array}{l}\text { WBCs number: } \\
\text { 13,800 } \mathrm{mL}^{-1} \text { (once); } \\
663 \mathrm{~mL}^{-1} \text { (twice) }\end{array}$ & - & $\begin{array}{l}\text { Breast }(n=56) \text {, pancreatic } \\
\qquad(n=20)\end{array}$ & [62] \\
\hline & $\begin{array}{l}\text { Micro-obstacles } \\
\text { spiral-chip }\end{array}$ & 390 & 22 & $>95 \%$ & - & $2.29 \times 10^{5}$ & - & [63] \\
\hline
\end{tabular}


Table 1. Cont

\begin{tabular}{|c|c|c|c|c|c|c|c|c|}
\hline $\begin{array}{l}\text { Separation } \\
\text { Principles }\end{array}$ & Technology & $\begin{array}{c}\text { Flow } \\
\text { Rate } \\
\left(\mathrm{mL} \mathrm{h}^{-1}\right)\end{array}$ & $\begin{array}{l}\text { Effective } \\
\text { Flow Rate } \\
\left(\mathrm{mL} \mathrm{h}^{-1}\right)\end{array}$ & Efficiency/Sensitivity & Capture Purity & $\begin{array}{c}\text { Enrichment } \\
\text { Factor }\end{array}$ & Clinical Sample & Ref. \\
\hline \multirow{7}{*}{$\begin{array}{c}\text { Physical } \\
\text { properties-based } \\
\text { methods }\end{array}$} & $\begin{array}{c}\text { Spiral } \\
\text { series-chip }\end{array}$ & $60-120$ & 2.4 & $73.75-80.75 \%$ & $63.6 \%$ & - & - & [64] \\
\hline & $\begin{array}{l}\text { Multistage } \\
\text { hydrodynamic } \\
\text { focusing-chip }\end{array}$ & $0.54-0.90$ & 0.90 & $>90 \%$ & $85 \%$ & - & Ovarian $(\mathrm{n}=1)$ & [65] \\
\hline & $\begin{array}{l}\text { Membrane } \\
\text { filtration }\end{array}$ & $12-60$ & $12-60$ & $>80 \%$ & $\begin{array}{l}\text { WBCs number: } \\
1000-3000 \mathrm{~mL}^{-1}\end{array}$ & - & - & [66] \\
\hline & Cluster-chip & 2.5 & 2.5 & $41 \%$ (two-cell) & - & - & $\begin{array}{l}\text { Breast }(n=27), \text { melanoma } \\
(n=20), \text { prostate }(n=13)\end{array}$ & [26] \\
\hline & $\begin{array}{l}\text { Conical-shaped } \\
\text { holes-chip }\end{array}$ & 12 & 4 & $96 \%$ & $\begin{array}{l}\text { WBC clearance } \\
\text { efficiency: } 96 \%\end{array}$ & $\sim 10^{2}$ & $\begin{array}{l}\text { Lung }(n=8) \text {, nasopharynx } \\
(n=2) \text {, mediastinal }(n=2) \text {, } \\
\text { cardia }(n=1) \text {, cervical } \\
(n=1) \text { and breast }(n=1)\end{array}$ & [67] \\
\hline & Ratchets-chip & 1 & 1 & $90 \%$ & - & $\sim 10^{4}$ & Prostate $(\mathrm{n}=20)$ & [68] \\
\hline & Parsortix-chip & 10 & 10 & $54-69 \%$ & $\begin{array}{l}\text { WBCs number: } \\
\text { 200-5000 } \mathrm{mL}^{-1}\end{array}$ & - & $\begin{array}{l}\text { Breast }(n=10), \text { colon } \\
(n=10) \text { and lung }(n=6)\end{array}$ & [69] \\
\hline
\end{tabular}




\subsection{Methods Based on Physical Properties}

The difference in physical properties can also be used to separate CTC from blood cells (including cell size, deformability, density, and dielectric properties, etc.). The most commonly used is the separation based on size and deformation. The diameter of CTC is 8-20 $\mu \mathrm{m}$ [70,71], the Young's modulus is 494-2472 $\mathrm{Pa}$ [72-74], while the diameter of WBC is $8-15 \mu \mathrm{m} \mathrm{[70],} \mathrm{and} \mathrm{its} \mathrm{Young's} \mathrm{modulus}$ is 48-156 Pa [75,76], the diameter of RBC and platelet is much smaller. Because the CTC is larger in size and is less deformable [77], it can be separated by ISET (isolation by size of epithelial tumor cells). It utilizes track-etched polycarbonate membranes with evenly distributed $8 \mu \mathrm{m}$-diameter cylindrical pores to filter the blood, after filtering, the larger CTCs are left on the membrane, and the smaller blood cells are filtered (Figure 2). In addition, researchers also developed various membrane filtration methods with different membrane pore sizes [66,78-80]. The difference in cell density can also be used to separate CTC. The sucrose density gradient centrifugation method uses sucrose to pre-form a concentration gradient, different types of cells are in different positions due to the difference in density and sedimentation coefficient, and the separation of CTC can be achieved (Figure 2) [81,82]. Taking advantage of the difference in physical properties between $\mathrm{CTC}$ and $\mathrm{WBC}$, and by rationally designing microfluidic chips, effective separation can also be achieved. For example, by designing some pillar arrays with suitable gaps, the gap allows WBCs and RBCs to pass through, while CTCs are stuck and captured (Figure 2) $[26,68,83]$. This can be called filtration-based microfluidic methods. In addition to these, there are microfluidic methods based on streamlines. Deterministic lateral displacement (DLD) $[54,84,85]$ and spiral designs [61-64,86] are often used to separate CTCs. The main principle is that cells reach an equilibrium position in the channel under the action of various forces (such as gravity, buoyancy, lateral force, and Dean force etc.), the equilibrium position is related to cell size, and then CTC can be separated from other blood cells (Figure 2).

In addition to the methods mentioned above, some researchers have also achieved size-based CTC separation by applying an external force: acoustic wave. The basic principle is that cell movement is caused by sound pressure waves generated by the transducer. The standing acoustic wave in the microfluidic channel has nodes and antinodes, cells flowing through these periodic pressure nodes and antinodes are subjected to different acoustic radiation forces, the force is proportional to the cell size, resulting in the difference in lateral displacement, and then realizes the separation of CTC $[87,88]$. Acoustophoresis-based CTC separation has the following advantages: it separates cells in a label-free, contact-free, and biocompatible manner, and retains cells' original state, integrity, and function [21]. However, the problem is that the flow rate is low $\left(1.2 \mathrm{~mL} \mathrm{~h}^{-1}\right)$ [89], and the blood needs to be lysed or diluted in a large proportion. Wu et al. used a polydimethylsiloxane (PDMS)-glass hybrid channel to increase the reflection of sound waves and reduced the velocity at the center of the channel by introducing a PDMS barrier in the middle of the channel, which effectively improved the separation efficiency and increased the flow rate to $7.5 \mathrm{~mL} \mathrm{~h}^{-1}$ [88].

Physical properties-based CTC separation does not rely on the expression of antigen on the cell surface, and can obtain both E-type and M-type CTCs. The separation process is high throughput (usually can reach tens of $\mathrm{mL} \mathrm{h}^{-1}$, which means a shorter process time), low cost and easy to operate. However, there are problems with CTCs capture efficiency and purity, because of the size overlap of WBCs and CTCs. In order to maintain high CTC capture efficiency, correspondingly, more WBCs will be captured (may reach tens of thousands per milliliter). Moreover, in order to achieve high purity, the CTC capture efficiency may decrease (Table 1).

\section{Electrochemical Detection of CTC}

In recent years, electrochemical detection of CTC has attracted widespread attention due to its advantages such as convenience, rapidity, low cost, high sensitivity, low detection limit, and strong specificity [90]. From the principle of separation, electrochemical detection of CTC is a kind of the biological properties-based CTC separation. However, it usually uses aptamer to replace traditional antibodies. Aptamer has similar specificity and affinity compared to antibodies, 
but it has many advantages, including easier to achieve large-scale production, lower cost, and lower immunogenicity $[22,91]$ This greatly reduces the cost of electrochemical detection. We summarized common aptamers used for CTC detection in Table 2, and listed their Kd values, targeted biomarkers, applicable cell lines and cancer types, etc. Most of these aptamers are dsDNA, and a small part are ssDNA or RNA.

The principle of electrochemical detection is to modify the electrode using nanomaterials and cancer cell specific aptamer, and CTC is bonded to aptamer (on the electrode surface), which will cause the current/electrochemiluminescence (ECL)/photoelectrochemical (PEC) signal to decrease or EC impedance spectroscopy (EIS) signal to increase [27,92-96]. By establishing a linear relationship between the change and the number of CTC, the quantification can be realized. The electrochemical CTC detection methods can be roughly divided into direct assays, sandwich assays and other assays [22]. The direct assays use nanomaterials-aptamer as the capture probe (which is directly modified on the electrode) to bind and detect CTC (Figure 2) [97]. The sandwich assays add a signal probe on the basis of direct assays, that is, after CTC is bound to the capture probe on the electrode, a signal probe (another kind of nanomaterials-aptamer) is added. After the signal probe is combined with CTC, it can significantly amplify the signal, thereby increasing the sensitivity and reducing the detection limit (Figure 2) [30,98,99]. We summarized the electrochemical-based CTC detection methods in Table 3, including the direct assay and the sandwich assay, and we listed the assay time, linear range, limit of detection, capture probe, and signal probe.

Table 2. Summary of aptamers used for CTC detection.

\begin{tabular}{|c|c|c|c|c|c|c|}
\hline Cancer Type & Cell Line & Aptamer & $\begin{array}{l}\text { DNA } \\
\text { or } \\
\text { RNA }\end{array}$ & Biomarker & $\mathrm{Kd} / \mathrm{nM}$ & Ref. \\
\hline \multirow{3}{*}{ Breast } & MCF-7/HeLa & AS1411 & DNA & $\begin{array}{l}\text { Overexpressed } \\
\text { nucleolin } \\
\text { on the cell } \\
\text { surface }\end{array}$ & $100-1000$ & [100] \\
\hline & MCF-7 & MUC 1 & DNA & $\begin{array}{l}\text { Overexpressed } \\
\text { mucin } 1 \text { (MUC1) } \\
\text { glycoprotein } \\
\text { on the cell } \\
\text { membrane }\end{array}$ & 38.3 & [101] \\
\hline & MCF-7/MDA-MB-231 & SYL3C & DNA & EpCAM & $38 \pm 9$ & $\begin{array}{l}{[102,} \\
103]\end{array}$ \\
\hline Leukemia & CCRF-CEM & $\operatorname{Sgc} 8 \mathrm{c}$ & DNA & $\begin{array}{c}\text { Tyrosine } \\
\text { kinase- } 7 \text { on the } \\
\text { cell surface }\end{array}$ & $2.0 \pm 0.2$ & [104] \\
\hline \multirow{4}{*}{ Lymphoma } & Toledo & Sgd5 & DNA & - & - & [105] \\
\hline & Ramos & Td05 & DNA & B-cell receptor & $74.8 \pm 8.7$ & $\begin{array}{l}{[105,} \\
106]\end{array}$ \\
\hline & Ramos & TE02 & DNA & - & $\begin{array}{c}0.76 \pm \\
0.13\end{array}$ & [106] \\
\hline & Karpas 299 & $\begin{array}{l}\text { Anti-CD30 } \\
\text { RNA } \\
\text { aptamer }\end{array}$ & RNA & CD30 & - & [107] \\
\hline
\end{tabular}


Table 2. Cont.

\begin{tabular}{|c|c|c|c|c|c|c|}
\hline Cancer Type & Cell Line & Aptamer & $\begin{array}{l}\text { DNA } \\
\text { or } \\
\text { RNA }\end{array}$ & Biomarker & $\mathrm{Kd} / \mathrm{nM}$ & Ref. \\
\hline $\begin{array}{l}\text { Colorectal, } \\
\text { glioblastoma } \\
\text { and lung }\end{array}$ & - & $\begin{array}{l}\text { Anti-EGFR } \\
\text { RNA } \\
\text { aptamer }\end{array}$ & RNA & $\begin{array}{l}\text { Epidermal } \\
\text { growth factor } \\
\text { receptor (EGFR) }\end{array}$ & 2.4 & $\begin{array}{l}{[108,} \\
109]\end{array}$ \\
\hline \multirow{2}{*}{ Liver } & Mear & TLS1c & ssDNA & & $\begin{array}{c}9.79 \pm \\
0.30\end{array}$ & $\begin{array}{l}{[110,} \\
111]\end{array}$ \\
\hline & HepG2/Mear & TLS11a & DNA & - & $\begin{array}{c}4.51 \pm \\
0.39\end{array}$ & $\begin{array}{l}{[110,} \\
111]\end{array}$ \\
\hline Lung & - & LC-18 & DNA & $\begin{array}{c}\text { Neutrophil } \\
\text { defensin } 1 \text { and } 3\end{array}$ & 38 & [112] \\
\hline Prostate & LNCaP & $\begin{array}{l}\text { A10 RNA } \\
\text { aptamer }\end{array}$ & RNA & $\begin{array}{l}\text { Prostate specific } \\
\text { membrane } \\
\text { antigen (PSMA) }\end{array}$ & 600 & $\begin{array}{l}{[113,} \\
114]\end{array}$ \\
\hline
\end{tabular}

\subsection{Direct Assays}

The principle of direct assays is based on the combination of CTC and electrode, thus affects the transfer of electrons, which in turn leads to a decrease in current/increase in electrical impedance [94,115], thereby realizing the quantitative detection of CTC. Many researchers use functionalized nanomaterials to modify the electrodes, the main purpose is to increase the contact area, enhance the conductivity, and then enhance the signal. Cao et al. proposed a method for detecting acute leukemia CCRF-CEM cells using a hybrid of nanochannels and ion channels arrays. The main principle is after modifying the sgc8c aptamer on the surface of the channel, CTC is combined with ion channel, then it will dramatically block the ionic flow through channels, which in turn causes current changes, using linear sweep voltammetry (LSV) cytosensor to record the change and to quantify CTC. Compared with a single channel, the array channels could amplify the signal and to improve the detection sensitivity. The linear range is $1 \times 10^{2}-2 \times 10^{6}$ cells $\mathrm{mL}^{-1}$, and the limit of detection (LOD) is 100 cells $\mathrm{mL}^{-1}$ (Figure 3A) [116]. Subsequently, Li et al. reported a PEC-based CTC detection method, hypotoxic ternary mercaptopropionic acid (MPA)-capped $\mathrm{AgInS}_{2}$ nanoparticles (NPs) as PEC sensing substrates, after being excited by red light, it shows high photon-current conversion efficiency, and generates strong photocurrent. After CCRF-CEM cell is connected to aptamers on $\mathrm{AgInS}_{2} \mathrm{NPs}$, the photocurrent is significantly reduced, and CTC can be detected. Its linear range is from $1.5 \times 10^{2}$ to $3.0 \times 10^{5}$ cells $\mathrm{mL}^{-1}$, and the LOD is 16 cells $\mathrm{mL}^{-1}$ (Figure 3C) [93]. In order to further improve the detection sensitivity, Wang et al. prepared nanomaterials-plasmonic gold nanostars (AuNSs), modified sgc8c aptamer on its surface and fixed it on glassy carbon (GC) electrode. The results showed that the LOD for CCRF-CEM cell is as low as 5 cells mL ${ }^{-1}$, in addition, MCF-7 cells could also be detected with a LOD of 10 cells mL $\mathrm{mL}^{-1}$ (Figure 3B) [117]. Liu et al. used ECL cytosensor for MCF-7 cell detection. Modified Au@CDs-aptamer on GC electrode, after adding $\mathrm{K}_{2} \mathrm{~S}_{2} \mathrm{O}_{8}$, Au@CDs showed strong electrochemiluminescence. Due to the combination of CTC, the strength of ECL will decrease. Its linear range was 100 to 10,000 cells $\mathrm{mL}^{-1}$ with a LOD of 34 cells $\mathrm{mL}^{-1}$ (Figure 3D) [92]. Graphene nanomaterials are also widely used in electrochemical detection of CTC due to their excellent electrical conductivity [118]. For example, $\mathrm{Zhang}$ et al. synthetized a $\mathrm{xFe}_{2} \mathrm{O}_{3}-\mathrm{nPt}$ (or nPt-xFe $\mathrm{O}_{3}$ )-coated graphene nanostructure ( $\mathrm{xFe}_{2} \mathrm{O}_{3}$-nPt@graphene) to detect MCF-7 cells using differential pulse voltammetry (DPV) cytosensor. The combination of graphene, $\mathrm{Pt}$ and $\mathrm{Fe}_{2} \mathrm{O}_{3}$ greatly reduced the electrode resistance and improved the electron transfer efficiency, and effectively amplified the signal and improved

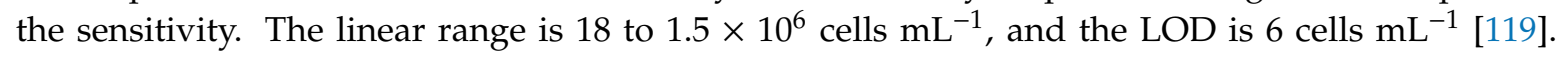
Bábelová et al. invented a method to detect leukemia, which is based on electrochemical impedance spectroscopy (EIS) and thickness shear mode acoustic method (TSM). It used sgc8c as the specific 
aptamer and achieved high-sensitivity detection of Jurkat cell. The LOD of electrochemical and acoustic sensors is $105 \pm 10$ and $463 \pm 50$ cells $\mathrm{mL}^{-1}$, respectively [120].

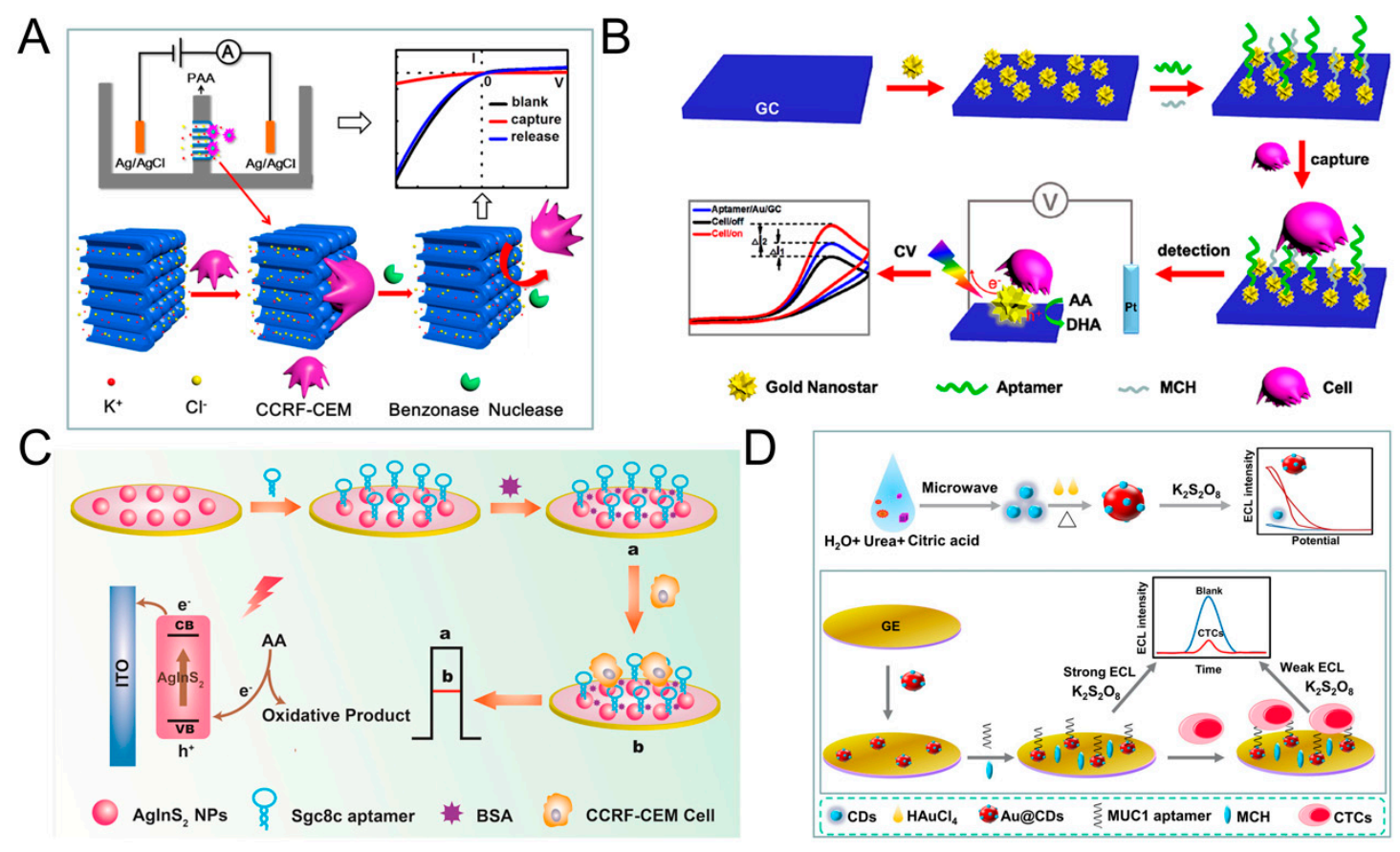

Figure 3. Direct electrochemical detection of CTC. (A) Linear sweep voltammetry (LSV) cytosensor for CCRF-CEM cell detection, using hybrid nanochannels and ion channels. Reprinted with permission from ref. [116]. Copyright 2017, American Chemical Society. (B) Cyclic voltammetry (CV) cytosensor for CCRF-CEM cell and MCF-7 cell detection, by modifying plasmonic gold nanostars (AuNSs)-aptamer on glassy carbon (GC) electrodes. Reprinted with permission from ref. [117]. Copyright 2019, American Chemical Society. (C) Photoelectrochemical (PEC) cytosensor for CCRF-CEM cell detection, using $\mathrm{AgInS}_{2}$ nanoparticles (NPs) coupled with sgc8c aptamer which exhibited high photon-to-current conversion efficiency under red light excitation. Reprinted with permission from ref. [93]. Copyright 2019, Elsevier. (D) Electrochemiluminescence (ECL) cytosensor for MCF-7 cell detection using $\mathrm{Au} @ \mathrm{CD}$ s-aptamer, after adding $\mathrm{K}_{2} \mathrm{~S}_{2} \mathrm{O}_{8}$, Au@CDs showed strong electrochemiluminescence. Reprinted with permission from ref [92]. Copyright 2020, Elsevier. 
Table 3. Summary of electrochemical CTC detection methods.

\begin{tabular}{|c|c|c|c|c|c|c|c|c|c|}
\hline & $\begin{array}{l}\text { Assay } \\
\text { Time } \\
\text { (min) }\end{array}$ & $\begin{array}{l}\text { Linear } \\
\text { Range } \\
(\text { Cells } \\
\mathrm{mL}^{-1} \text { ) }\end{array}$ & $\begin{array}{l}\text { LOD } \\
(\text { Cells } \\
\left.\mathrm{mL}^{-1}\right)\end{array}$ & Aptamer/Antibody & $\begin{array}{l}\text { Target } \\
\text { Cell }\end{array}$ & Capture Probe & Signal Probe & $\begin{array}{l}\text { Clinical } \\
\text { Sample }\end{array}$ & Ref. \\
\hline \multirow{5}{*}{ Direct assay } & 70 & $\begin{array}{c}18-1.5 \times \\
10^{6}\end{array}$ & 6 & AS1411 & MCF-7 & $\begin{array}{c}\mathrm{xFe}_{2} \mathrm{O}_{3}-\mathrm{nPt} \text { (or } \\
\mathrm{nPt}-\mathrm{xFe}_{2} \mathrm{O}_{3} \text { )-coated } \\
\text { graphene } \\
\text { nanostructure+aptamer }\end{array}$ & - & $\begin{array}{l}\text { Spiked blood } \\
\text { samples }\end{array}$ & [119] \\
\hline & 45 & $\begin{aligned} 1 & \times 10^{2}-2 \\
& \times 10^{6}\end{aligned}$ & 100 & $\operatorname{sgc} 8 \mathrm{c}$ & CCRF-CEM & $\begin{array}{l}\text { Nanochannel-ion channel } \\
\text { +aptamer }\end{array}$ & 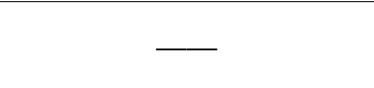 & - & [116] \\
\hline & 90 & $100-10,000$ & 34 & anti-MUC 1 aptamer & MCF-7 & $\begin{array}{c}\text { Gold electrode+Au@CDs } \\
+ \text { aptamer }\end{array}$ & - & $\begin{array}{l}\text { Human serum } \\
\text { samples }\end{array}$ & [92] \\
\hline & 45 & $5-1 \times 10^{5}$ & 5 & $\operatorname{sgc} 8 \mathrm{c}$ & CCRF-CEM & $\begin{array}{l}\text { Glassy carbon electrode } \\
+ \text { AuNSs+aptamer }\end{array}$ & - & $\begin{array}{l}\text { Human serum } \\
\text { samples and } \\
\text { spiked blood } \\
\text { samples }\end{array}$ & [117] \\
\hline & 60 & $\begin{array}{l}1.5 \times 10^{2}-3 \\
\times 10^{5}\end{array}$ & 16 & $\operatorname{sgc} 8 \mathrm{c}$ & CCRF-CEM & $\begin{array}{l}\text { AgInS }_{2} \text { NPs-modified } \\
\text { electrode+aptamer }\end{array}$ & - & - & [93] \\
\hline \multirow{4}{*}{$\begin{array}{l}\text { Sandwich } \\
\text { assay }\end{array}$} & 120 & $75-5500$ & 75 & E-cadherin & $\begin{array}{c}\text { Not } \\
\text { limited }\end{array}$ & CNT-AuNPs+antibody & E-cadherin antibody+QD & $\begin{array}{c}\text { Fetal calf } \\
\text { serum and } \\
\text { mouse blood }\end{array}$ & [121] \\
\hline & 50 & $\begin{aligned} 1 & \times 10^{2}-5 \\
& \times 10^{4}\end{aligned}$ & 5 & SYL3C & MCF-7 & m-aptamer/MCH/AuE & $\begin{array}{l}\text { Anti-EpCAM/HRP- } \\
\text { AuNP }\end{array}$ & $\begin{array}{l}\text { Spiked blood } \\
\text { samples }\end{array}$ & [28] \\
\hline & \multirow[t]{2}{*}{20} & \multirow[t]{2}{*}{$5-500$} & 4 & Td05 & Ramos & \multirow[t]{2}{*}{ AuNPs- $\mathrm{Fe}_{3} \mathrm{O}_{4}$-GS+aptamer } & \multirow{2}{*}{$\begin{array}{l}\text { AuNPs with the } \\
\text { electroactive species } \\
\text { (Fc-SH/Thi) +aptamer }\end{array}$} & \multirow{2}{*}{$\begin{array}{l}\text { Spiked blood } \\
\text { samples and } 3 \\
\text { leukemia } \\
\text { patients }\end{array}$} & \multirow[t]{2}{*}{ [98] } \\
\hline & & & 3 & $\operatorname{Sgc} 8$ & CCRF-CEM & & & & \\
\hline
\end{tabular}


Table 3. Cont

\begin{tabular}{|c|c|c|c|c|c|c|c|c|c|}
\hline & $\begin{array}{l}\text { Assay } \\
\text { Time } \\
\text { (min) }\end{array}$ & $\begin{array}{l}\text { Linear } \\
\text { Range } \\
(\text { Cells } \\
\mathrm{mL}^{-1} \text { ) }\end{array}$ & $\begin{array}{l}\text { LOD } \\
(\text { Cells } \\
\left.\mathrm{mL}^{-1}\right)\end{array}$ & Aptamer/Antibody & $\begin{array}{l}\text { Target } \\
\text { Cell }\end{array}$ & Capture Probe & Signal Probe & $\begin{array}{l}\text { Clinical } \\
\text { Sample }\end{array}$ & Ref. \\
\hline \multirow{5}{*}{$\begin{array}{l}\text { Sandwich } \\
\text { assay }\end{array}$} & 40 & $10-1 \times 10^{6}$ & 2 & EpCAM+vimentin & MCF-7 & $\begin{array}{l}\text { Ketjen black+AuNP } \\
\text { +antibody }\end{array}$ & PdIrBPMNS+antibody & $\begin{array}{l}\text { Spiked blood } \\
\text { samples }\end{array}$ & [29] \\
\hline & 170 & $3-3000$ & 1 & $\begin{array}{l}5^{\prime} \text {-thiol modified } \\
\text { MCF-7 binding } \\
\text { aptamer }\end{array}$ & MCF-7 & $\mathrm{MN}+\mathrm{EpCAM}$ & $\mathrm{Cu}_{2} \mathrm{O}+$ aptamer & $\begin{array}{l}\text { Spiked blood } \\
\text { samples }\end{array}$ & [30] \\
\hline & 60 & $3-1000$ & 1 & anti-MUC 1 aptamer & MCF-7 & $\mathrm{MN}+\mathrm{EpCAM}$ & $\mathrm{LiFePO}_{4} / \mathrm{Au}+$ aptamer & $\begin{array}{l}\text { Spiked blood } \\
\text { samples }\end{array}$ & [27] \\
\hline & 115 & $5-3 \times 10^{4}$ & 1 & SYL3C-RCA primer & MCF-7 & $\mathrm{MN}+\mathrm{EpCAM}$ & $\begin{array}{c}\text { Aptamer+DNA } \\
\text { amplification (RCA) }\end{array}$ & $\begin{array}{l}\text { Spiked blood } \\
\text { samples }\end{array}$ & [99] \\
\hline & 40 & $20-1 \times 10^{6}$ & 3 & EpCAM & MCF-7 & $\begin{array}{c}\text { Au electrode }+\mathrm{AB} \\
+\mathrm{AuNP}+\text { proteinG+antibody }\end{array}$ & Pt@AgNFs+antibody & $\begin{array}{l}\text { Spiked blood } \\
\text { samples }\end{array}$ & [94] \\
\hline
\end{tabular}




\subsection{Sandwich Assays}

The sandwich assays add a signal probe on the basis of direct assays. The capture probe is fixed on the electrodes to identify and capture CTC. The signal probe is used for amplifying the signal, improving the sensitivity, and reducing the detection limit $[27,94,122]$. Signal probes are usually some active nanomaterials or particles with enzymatic activity.

Shen et al. used magnetic nanospheres modified with anti-EpCAM antibody to capture MCF-7 cells. The captured MCF-7 cells are spread on the electrode surface, aptamer (SYL3C-RCA primer) is added and bound to the cells, by rolling circle amplification (RCA), producing a large amount of DNA molecules and reacting with the substrate to amplify the electrochemical current signal. The linear range is 5-3 $\times 10^{4} \mathrm{~mL}^{-1}$, and the detection limit can reach 1 cell $\mathrm{mL}^{-1}$ (Figure 4F) [99]. RCA technology was also used by other groups [28,123]. For example, Yang et al. used RCA reaction to expand the initial $\mathrm{PD} / \mathrm{CDT}$ so that the expanded DNA chain contains multiple duplicate aptamers. The expanded DNA strand as a capture probe has the following advantages: (1) This flexible long DNA chain can extend to the depth of the cell suspension, which allows the aptamers in full contact with the target cells; (2) The aptamer binds to the target cell in a multivalent manner, effectively improve the capture efficiency of target cells. The signal probe anti-EpCAM/Horseradish peroxidase (HRP)-gold nanoparticles (AuNP) is used to catalyze $\mathrm{H}_{2} \mathrm{O}_{2}$ to generate electrical signals for detection. The linear range is $1 \times 10^{2}-5 \times 10^{4} \mathrm{~mL}^{-1}$, and the LOD is 5 cell $\mathrm{mL}^{-1}$ (Figure 4E) [28].

Tang et al. modified AuNPs/Acetylene black (AuNPs/AB) on the gold electrode to increase the specific surface area and enhance the conductivity of the gold electrode. Then anchored antibody on the surface of AuNPs/AB to capture MCF-7 cells. After capture, the signal probe Pt@AgNFs was added, which can catalyze $\mathrm{H}_{2} \mathrm{O}_{2}$ to generate electrical signals. The linear range is $20-1 \times 10^{6}$, and the detection limit is 3 cells $\mathrm{mL}^{-1}$ (Figure 4A) [94]. Luo et al. proposed a PEC biosensor-based CTC detection method with higher sensitivity using antibody-magnetic nanospheres to capture MCF-7 cells. After spreading the capture cells on the electrode, the photocurrent intensity of hexagonal carbon nitride tubes (HCNT) is reduced due to the steric hindrance derived from MCF-7. After adding a signal probe $\mathrm{Cu}_{2} \mathrm{O}$ NPs, the photocurrent intensity of was further decreased because $\mathrm{Cu}_{2} \mathrm{O}$ NPs competitively absorbed the excitation light, and the aptamer molecules further increased the steric hindrance, the linear range is $3-3000$ cell mL $\mathrm{m}^{-1}$, and the detection limit is 1 cell $\mathrm{mL}^{-1}$ (Figure 4D) [30]. Similarly, Zhang et al. also used antibody-magnetic nanospheres to capture MCF-7 cells, and after coating the cells on the electrode, used gold nanoparticle-modified $\mathrm{LiFePO}_{4}$ coupled with the aptamer as a signal probe, due to the reaction of phosphate group in $\mathrm{LiFePO}_{4}$ with molybdate that formed redox molybdophosphate $\left(\mathrm{PMo}_{12} \mathrm{O}_{40}\right)$ precipitates and caused current change. The linear range is $3-1000$ cells $\mathrm{mL}^{-1}$, and the LOD is 1 cell $\mathrm{mL}^{-1}$ (Figure 4B) [27]. The above parts are all about the detection of one type of cell. Using multiple different aptamers can simultaneously detect multiple types of cells. For example, Dou et al. used AuNPs-Fe $\mathrm{O}_{4}$-graphene nanosheets (GS) as the capture probe, AuNPs coupled with aptamer (Td05/Sgc8) and decorated with the electroactive species (Fc-SH/Thi) as the signal probe, and simultaneously achieved the quantitative detection of Ramos and CCRF-CEM cells, the detection limit is 4 and 3 cells $\mathrm{mL}^{-1}$, respectively. Further, the linear range is $5-500$ cells $\mathrm{mL}^{-1}$. More importantly, they also performed testing of three leukemia patients and showed obvious results (Figure 4C) [98]. Du et al. proposed a Cyclic voltammetry (CV) cytosensor based CTC electrochemical detection, and it can specifically detect the change of E-cadherin and analyze different stages of EMT. They modified CNT-AuNPs on the electrode surface, and then used quantum dot (QD) coupled anti E-cadherin antibody to bind to CTC. QD itself acts as a signal probe to enhance electrical signal, and at the same time, QD can also provide a strong fluorescent signal for imaging [121]. 

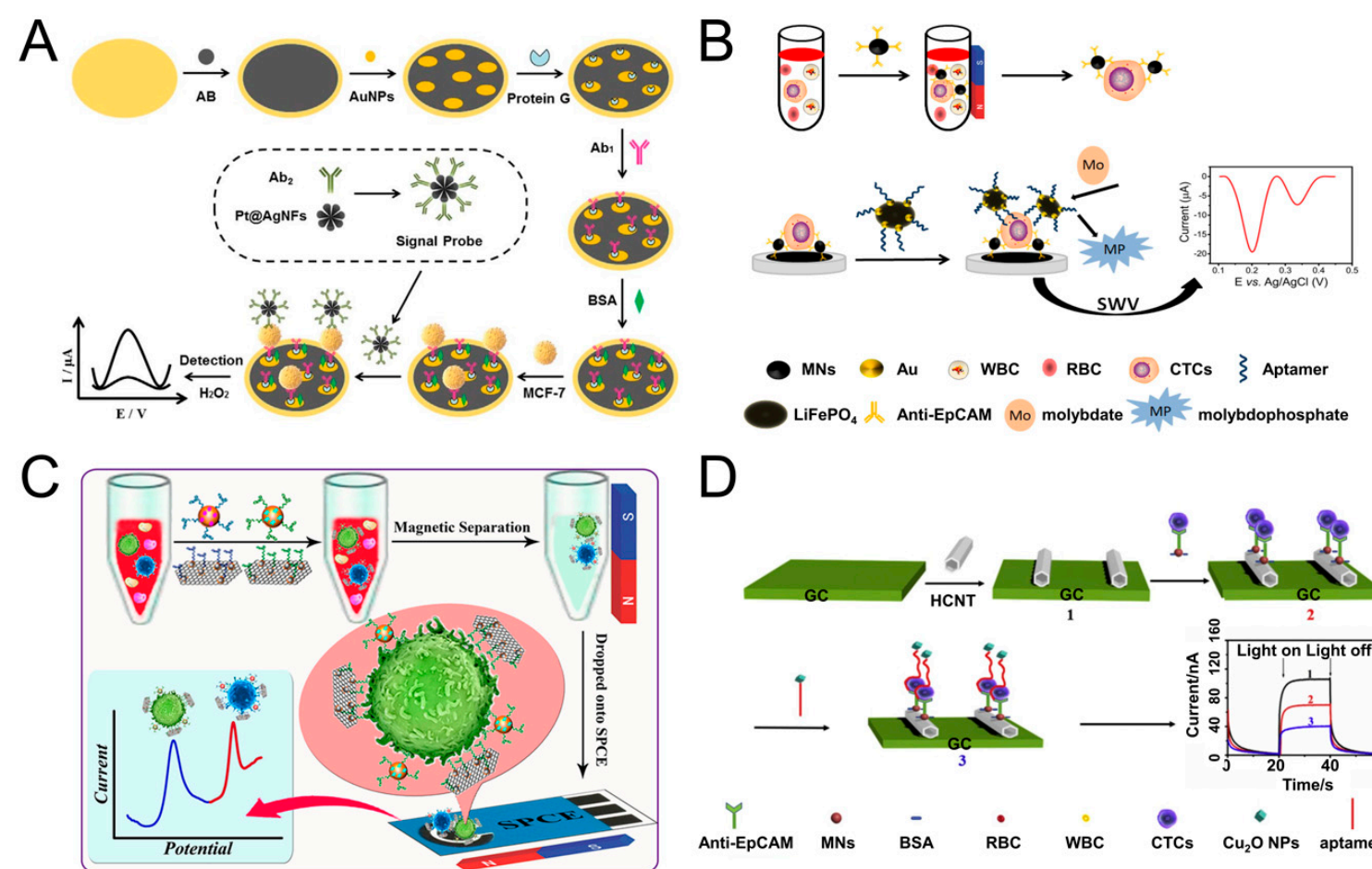

D

E

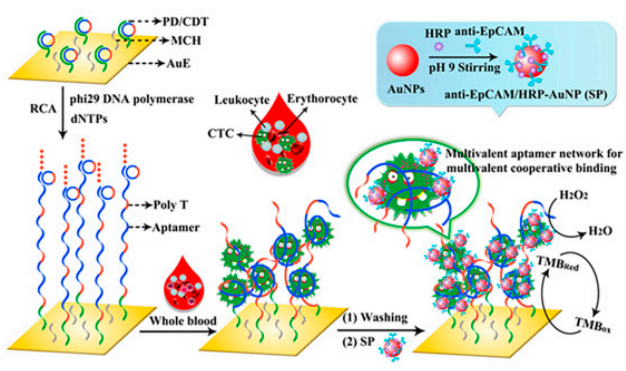

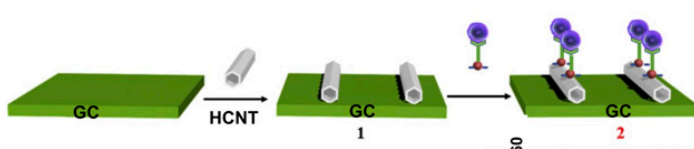

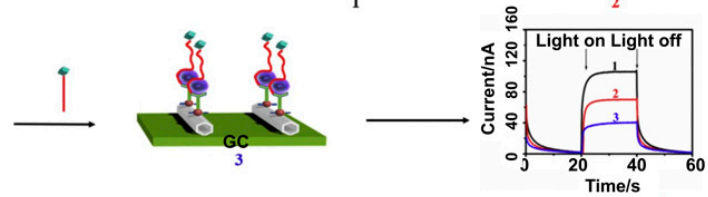

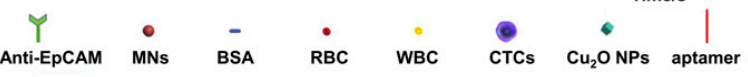

F

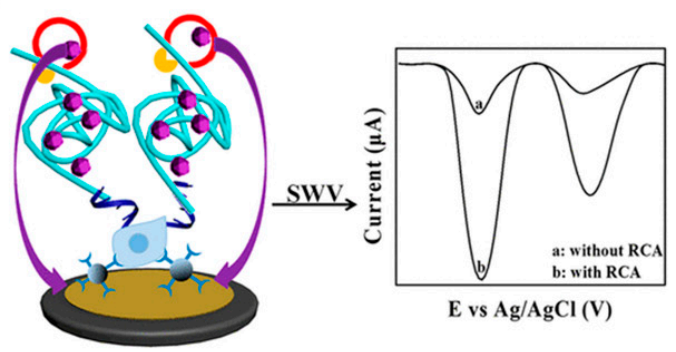

Figure 4. Sandwich electrochemical detection of CTC. (A) Voltammetric cytosensor for differential pulse voltammetry (DPV) detection of MCF-7 cells, using AuNPs/Acetylene black-antibody as capture probe and Pt@Ag nanoflowers-antibody as signal probe. Reprinted with permission from ref [94]. Copyright 2018, Elsevier. (B) Voltammetric cytosensor for square wave voltammetry (SWV) detection of MCF-7 cells, anti-EpCAM antibody-modified $\mathrm{Fe}_{3} \mathrm{O}_{4}$ magnetic nanospheres (MNs) were used to capture CTC, and gold nanoparticles modified $\mathrm{LiFePO}_{4}\left(\mathrm{LiFePO}_{4} / \mathrm{Au}\right)$ particles were used as signal probe. Reprinted with permission from ref. [27]. Copyright 2020, Elsevier. (C) Voltammetric cytosensor for SWV detection of CCRF-CEM cells, Au nanoparticles (AuNP) array-decorated magnetic graphene nanosheet as capture probe and aptamer/electroactive species-loaded AuNP as signal probe. Reprinted with permission from ref [98]. Copyright 2019, American Chemical Society. (D) Photoelectrochemical (PEC) cytosensor for detection of MCF-7 cells, Magnetic $\mathrm{Fe}_{3} \mathrm{O}_{4}$ nanospheres (MNs) as capture probe and $\mathrm{Cu}_{2} \mathrm{O}$ nanoparticles as signal probe. Reprinted with permission from ref [30], Copyright 2020, Elsevier. (E) Cyclic voltammetry (CV) cytosensor for MCF-7 cell detection, via rolling circle amplification (RCA) extension of the electrode-immobilized primer/circular DNA complexes as the capture probe, and anti-EpCAM/HRP-AuNP as signal probe. Reprinted with permission from ref [28]. Copyright 2020, American Chemical Society. (F) Voltammetric cytosensor for SWV detection of MCF-7 cells, anti-EpCAM antibody-modified magnetic nanospheres were used to capture and enrich CTC, and aptamer-primer DNA sequence as a signal probe, by RCA, produced a large amount of DNA molecules and reacted with the substrate to amplify the signal. Reprinted with permission from ref [99]. Copyright 2019, American Chemical Society. 
In Table 3, we can see that, compared to the direct method, sandwich assays have higher sensitivity, and its LOD can be as low as 1 cell $\mathrm{mL}^{-1}$. However, the detection time may be longer. In addition, the fabrication and detection process are also more complicated. The common problems are the narrow range of applicable cell types and very few clinical trials.

\subsection{Other Assays}

There are some electrochemical methods that only use electrochemical principles to achieve the enrichment and capture (or release) of CTC, while they do not use photoelectric signals to quantify CTC. We classify these methods as other assays [124,125].

Yan et al. set a series of elliptical pillars on the surface of the Polydimethylsiloxane (PDMS) chip, coated with electroconductive gold layer, and then coupled with EpCAM antibody to capture CTC. A capture efficiency of $85-100 \%$ was achieved for different cell lines both in buffer and in blood. More importantly, because the chip is conductive, it can easily release the captured cells for subsequent culture $(-1.2 \mathrm{~V}, 10 \mathrm{~min}$, survival rate after release $>95 \%)$ and lysis the cells for PCR analysis $(20 \mathrm{~V}, 10 \mathrm{~min})$. It is worth mentioning that this method also has a high capture efficiency for cells with low EpCAM expression (Figure 5C) [125]. Similarly, Zhai et al. also reported a highly efficient method to capture and release CCRF-CEM cells, but using aptamers modified gold nanowire arrays (AuNWs). The distance between AuNWs is narrower, about 110 to $130 \mathrm{~nm}$. Compared with directly coupling aptamer on the flat gold substrate, aptamers modified AuNWs effectively improved the capture efficiency of CCRF-CEM Cells (from 9\% to 83\%). CCRF-CEM Cells could be easily released by applying a voltage of $1.2 \mathrm{~V}$ for $30 \mathrm{~s}$, the release efficiency is $96.2 \%$, and the survival rate after release is about $90 \%$ (Figure 5B) [126]. Subsequently, Zhang et al. modified APBA+dopamine+sgc8c on the surface of poly(APBA-co-ABSA), and the capture efficiency of CCRF-CEM cells reached 83\%. After applying $0.6 \mathrm{~V}$ voltage for $120 \mathrm{~s}$, the boronic ester linkage between boric acid and dopamine was broken, and $88 \%$ of the cells were released, and the cell survival rate after release was 98\%. This method provides a gentle, fast, and non-invasive release of cells (Figure 5D) [127]. Gurudatt et al. designed an electrochemical-based CTC separation and enrichment method. By modifying the lipid bilayer on the surface of the channel and applied an AC electric field to make the cells move in a wave-like manner in the channel, and the passage time is related to the cell size and charge. Therefore, the separation of CTCs from WBCs and RBCs is realized. The separate efficiency is $92.0 \pm 0.5 \%$. The detection of CTC is based on the redox reaction of DM (daunomycin) molecules (coated on the CTC) to generate electrical signals. Blood samples from 37 cancer patients were tested with 90.9\% detection rate (Figure 5A) [128]. 


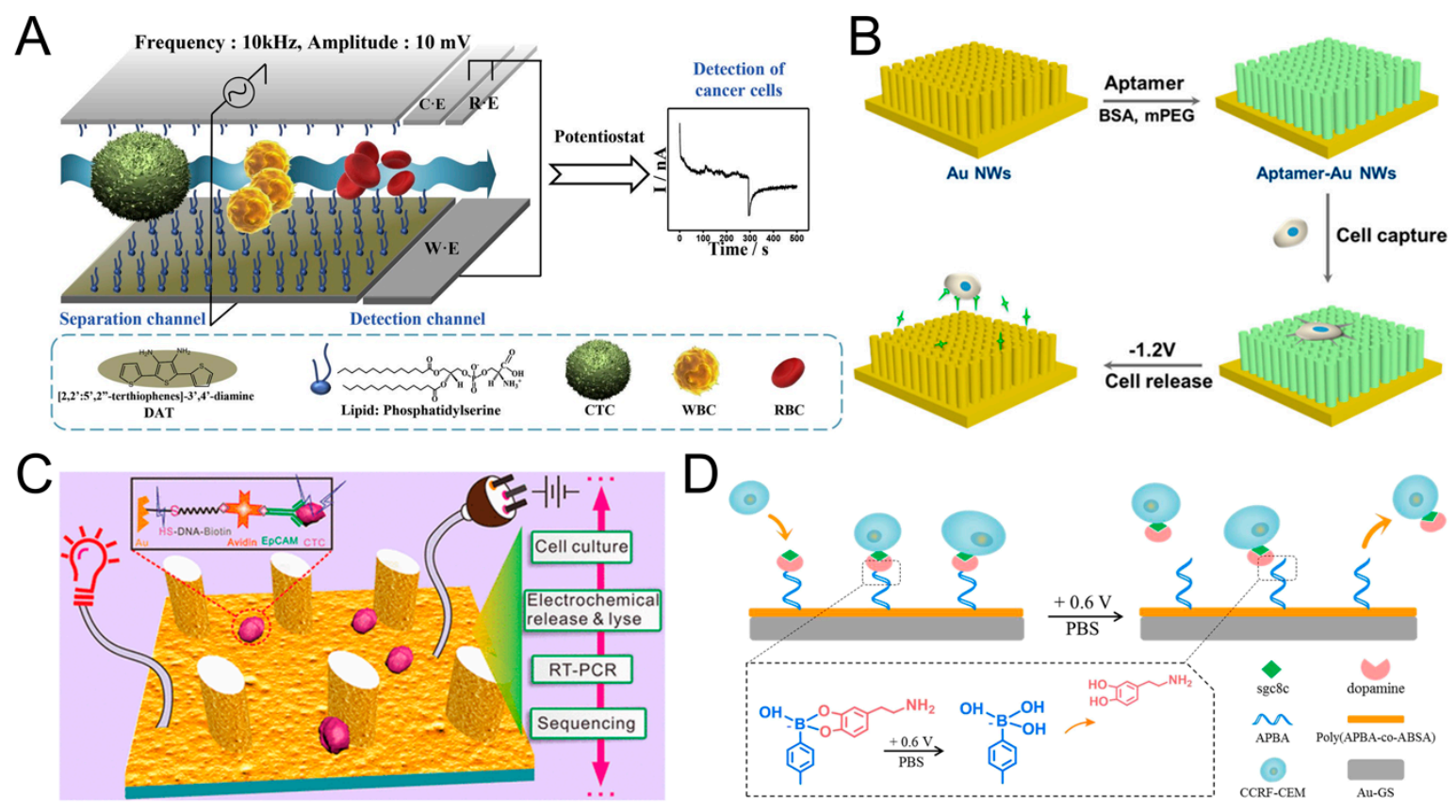

Figure 5. Other electrochemical detection methods of CTC. (A) Modified the surface of the channel with lipid bilayer, and realized CTC separation and detection by applying AC electric field. Reprinted with permission from ref [128]. Copyright 2019, Elsevier. (B) Fabricated gold nanowires coupled with aptamer, and achieved CTC capture and release. Reprinted with permission from ref [126]. Copyright 2017, American Chemical Society. (C) Set a series of elliptical columns on the surface of the PDMS chip, coated with $\mathrm{Au}$, and realized the capture release and lysis of CTC. Reprinted with permission from ref [125]. Copyright 2017, American Chemical Society. (D) Modified APBA-dopamine-sgc8c on the surface of poly(APBA-co-ABSA), promoted the capture and fast, efficient release of CTC. Reprinted with permission from ref [127]. Copyright 2019, Elsevier.

\section{Detection Method Based on Point-of-Care Testing (POCT)}

POCT refers to a clinical test that can be performed on the patient's bedside without the need for complicated equipment and specialized laboratory examiners. It samples on-site and analyzes immediately, eliminating the complicated processing procedures required for sample testing in the laboratory and quickly obtaining medical test results [129]. At present, the most commonly used POCT include blood glucose test paper and urine pregnancy test paper. In addition, POCT has other applications, including serum separation, detection of enzyme activity, detection of bacteria, viruses, proteins, DNA, etc. [31]. The methods based on POCT can be divided into self-driving testing and external force-driving testing according to driving force [31]. Self-driving detection includes the use of capillary effect, negative pressure, or chemical reaction to generate gas $[32,130]$, etc. to promote the reaction and output related signals, the external force-driving detection usually uses hand push, finger trigger button etc. as the driving force to promote the reaction. The most important thing is that the output signal of POCT is very simple and easy to get, usually including color, distance, pressure, temperature, etc. [131-135].

\subsection{POCT Based Detection of Enzyme Activity/Proteins/Compound}

Wang et al. immobilized telomerase primer (TS) on the surface of magnetic bead (MB), and the primer could be extended under the action of telomerase, and formed a single-stranded DNA containing (TTAGGG) repeating unit, the repeating unit can specifically bind to cDNA- nanoparticles (PtNPs), using the $\mathrm{H}_{2} \mathrm{O}_{2}$ catalytic ability of PtNPs, adding substrate $\mathrm{H}_{2} \mathrm{O}_{2}$, the gas is generated and the pressure changed. Using a portable pressure gauge to detect the change of the pressure could achieve the detection of single cell telomerase activity (Figure 6C) [134]. 
Ma et al. also designed a POCT based method to detect telomerase activity. They hybridized the magnetic beads with the capture DNA and the report DNA-functionalized enzyme. In the presence of telomerase, the TS primer was extended to generate a repetitive sequence and matched with the report DNA-functionalized enzyme. As the concentration of telomerase increased, more reported DNA-functionalized enzyme (includes alkaline phosphatase (ALP) and galactosidase (Gala)) remained in the solution, and Gala catalyzed luciferin di- $\beta$-D-pyridine Galactoside (FDG) hydrolyzed into FMG to produce a fluorescent signal. ALP catalyzes p-nitrophenyl phosphate (pNPP) to produce dark yellow p-nitrophenol ( $\mathrm{pNP}$ ), which caused a color change for colorimetric determination. In addition, ALP also catalyzed the hydrolysis of ATP to AMP, which can be detected by a portable ATP meter. The detection limit can be as low as a single cell $\mathrm{mL}^{-1}$, and it has been verified by patients [136]. Cao et al. quantified ALP activity by measuring distance. The entire system only needs an electrophoresis titration (ET) chip, a lithium battery, a UV LED, and an iPhone as a recorder, without other complicated power supplies and fluorescence detectors. The principle of the testing is based on the ability of ALP to react with the substrate. The product can produce fluorescence under UV excitation, and could move under an external electric field, and interacted with Tris- $\mathrm{HCl}$ buffer to produce a moving reaction boundary (MRB). ALP activity could be quantified by measuring the distance of MRB. The mobile phone can be used for data collection and analysis (Figure 6B) [132]. Recently, Wang et al. also used a smart phone, to determine anthrax based on color change, using $\mathrm{Eu}$ (III) functionalized carbon dots (CDs-Eu) as a fluorescent probe, where DPA (an anthrax biomarker) can interact with $\mathrm{CDs}$-Eu, resulting in a color change. Using the color analysis software on the smartphone, DPA can be quantified, and its linear range is $0.5 \mathrm{nM}$ to $5 \mu \mathrm{M}$ with a LOD of $0.8 \mathrm{nM}$ (Figure 6D) [131]. Xiao et al. designed an optical microfiber sensor modified by a polystyrene@gold nanosphere to detect the (CEA)-related cell adhesion molecules 5 (CEACAM5) concentration in serum. After CEACAM5 was bonded on the microfiber surface, the refractive index (RI) increased and the transmission of the optical sensor was found to redshift. The distance of the redshift is related to the concentration of CEACAM5. The LOD is $3.54 \times 10^{-17} \mathrm{M}$ in pure solution, $5.27 \times 10^{-16} \mathrm{M}$ in serum, about 6 orders of magnitude lower than current methods [137]. The proposed medical smartphone-powered dongle was demonstrated to be a very promising platform as a miniaturized electrochemical analyzer for point-of-care monitoring of the critical biochemical parameters such as blood ketone and a good solution for mobile health management. Ainla et al. designed a "universal wireless electrochemical detector" (UWED). It can perform routine electrochemical detection such as potentiometry, chronoamperometry, cyclic voltammetry and square wave voltammetry, at the same time, it has the following advantages compared with benchtop commercial potentiostats, which is simple, small in size, and inexpensive. This detector was connected to a smartphone (or a tablet) using "Bluetooth Low Energy" protocol, and the results of electrochemical detection can be immediately displayed on the mobile phone. It facilitates POCT-based electrochemical detection [138]. Guo et al. also proposed a POCT-based electrochemical method, they used dongle which is similar to UWED mentioned above. Their main purpose is to detect blood ketone in finger whole blood, it can help us to assess the progress of diabetic ketoacidosis (DK) and diabetic ketosis acid (DKA) diabetes. To be specific, they connected a mobile phone, a dongle, and a disposable electrochemical ketone test strip together. Among them, the test strip as a biosensor, underwent a series of redox reactions to convert the concentration of ketone into electric current. The dongle acted as a miniaturized electrochemical analyzer, and helped to present electrochemical results on the mobile phone. The whole system was cheap and simple, and its LOD can reach $0.001 \mathrm{mmol} \mathrm{L}^{-1}$ with a linear range of $0.001-6.100 \mathrm{mmol} \mathrm{L}^{-1}$ [139]. 


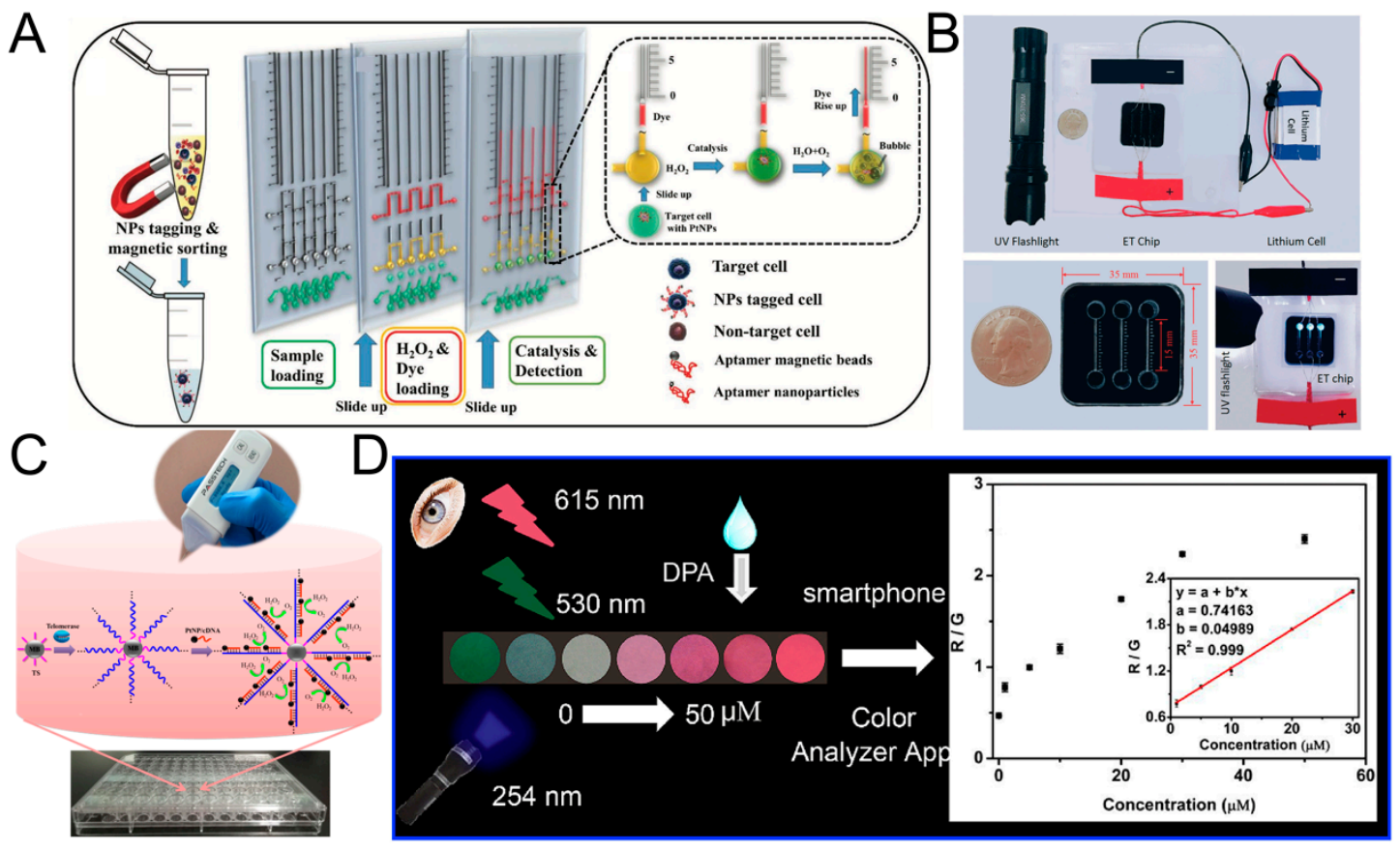

Figure 6. Point-of-Care testing devices. (A) Detecting the number of CTC based on distance, by labelling CTC with aptamer-conjugated nanoparticles (ACNP), which has hydrogen peroxide catalytic activity, in the presence of hydrogen peroxide, gas is generated to push the red ink to move, and the distance can be read. Reprinted with permission from ref [133]. Copyright 2019, John Wiley and Sons. (B) Quantify the activity of alkaline phosphatase (ALP) by distance. Reprinted with permission from ref [132]. Copyright 2018, Royal Society of Chemistry. (C) Use a portable pressure gauge to detect the pressure, to detect the telomerase activity of a single cells. Reprinted with permission from ref [134]. Copyright 2017, American Chemical Society. (D) A color-based method to detect anthrax biomarker DPA. Reprinted with permission from ref [131]. Copyright 2020, Elsevier.

\subsection{POCT Based Detection of CTC}

The above tests are all about detecting some simple enzyme activities or simple proteins/compounds. Due to the catalytic activity and high specificity of enzymes, the definite structure of protein or compounds, it is easy to find suitable substrates or suitable signal probes to detect them. However, it is difficult to detect CTC by POCT, because the number of CTC in the blood is rare, and there are a large number of background cells (including WBCs and RBCs) in the blood. These background cells can interfere with the detection of CTC. This poses a challenge to the sensitivity and specificity of the detection system. Apart from this, the heterogeneity of CTC makes its surface composition very complex $[15,140,141]$, and it is difficult for us to directly quantify using a simple general method, since there is a lack of CTC markers that are truly universally applicable with highly specificity. Recently, Abate et al. labeled CTC with aptamer-conjugated nanoparticles (ACNPs), and ACNP can catalyze the decomposition of $\mathrm{H}_{2} \mathrm{O}_{2}$. The by-product (oxygen) of the catalytic reaction caused the red ink to move, the moving distance is linearly related to cell concentration. The detection limit can be as low as a single cell $\mathrm{mL}^{-1}$, and the linear range is $0-2000$ cells $\mathrm{mL}^{-1}$ (Figure 6A) [133]. Moreover, the change of temperature could also be used to detect cancer cells. Zhang et al. connected graphene oxide (GO) and anti-EpCAM antibodies to microbeads, and microbeads could bind to the surface of cancer cells. Since magnetic microbeads and GOs have the photothermal effect, they will generate temperature changes when irradiated with laser. By establishing a linear relationship between temperature changes and the number of cancer cells, quantitative detection of cancer cells can be achieved, the detection limit is 100 cells $\mathrm{mL}^{-1}$ [135]. Yang et al. used two kinds of antibodies as capture probe and signal probe, respectively, and realized POCT-based CTC detection. The specific process is to use SK-BR-3 cells to simulate CTCs in blood, use anti-EpCAM antibody-functionalized magnetic beads 
as the capture probe to enrich and separate tumor cells, and then use anti-HER2 antibody and invertase co-modified polystyrene microspheres as signal probes. The substrate sucrose is converted into glucose under the action of invertase. By using the common glucose meter transducer, CTC detection was achieved. The linear range is $50-1000$ cells $\mathrm{mL}^{-1}$ with a detection limit of 7 cells $\mathrm{mL}^{-1}$ [142]. Xia et al. came up with an electrochemical-based point-of-care CTC detection method. CTCs were firstly captured by aptamer-modified magnetic beads, and then they can sequestrate ferroceneboronic acid (FcBA) or 4-mercaptophenylboronic acid (MPBA) by the formation of boronate ester bonds, thus leading to the decrease in the electrochemical signal of FCBA or preventing the MPBA-triggered aggregation of AuNPs, which leads to changes in electrochemical signal or color. The colorimetric assays achieved a linear range of $50-1.5 \times 10^{4}$ cells mL ${ }^{-1}$ with a sensitivity of 50 cells mL ${ }^{-1}$ [143].

\section{Conclusions and Future Trends}

In this review, we summarized the latest developments in electrochemical detection of CTC. In general, the detection of CTC by electrochemical methods has the following advantages: convenient, fast, low cost, high sensitivity and does not require complex equipment. However, there are also some problems which limit its clinical application: (1) The types of stable and high-affinity aptamers are too limited, only a few types of cancer cells could be used, mainly including CCRF-CEM cells and MCF-7 cells. (2) The sensitivity is still not high enough, it is difficult to achieve a LOD of $1 \mathrm{~mL}^{-1}$. (3) The current tests are more biased towards the laboratory, and the real patient-based blood tests are few. Compared to the medium system, the capture efficiency of blood-based tests will decrease, mainly due to the interference of ultra-high density of blood cells and complex components in the blood [99], which will cover the capture site or affect the progress of the reaction, thereby affecting the output of the electrochemical signal. For the popularization of the clinical application with electrochemical detection of CTC, efforts need to be made in the following directions: (1) Find more suitable CTC universal aptamers, because aptamer determines the specificity and accuracy of the detection, and determines the types of cancer that can be detected. More importantly, CTC are usually different from laboratory cell lines, the application of aptamers on CTC needs further exploration; (2) Further improve the sensitivity of detection, develop new catalytic nanomaterials as capture probes/signal probes to further amplify electrochemical signals; (3) Try to avoid interference caused by non-specific adsorption of blood cells, which may require us to pre-enrich the CTC in the blood. By integrating pre-enrichment strategy and electrochemical-based detection may be a more efficient and convenient method.

As for the application of POCT in CTC detection, although there are not many studies reported so far, it is a very promising development trend. Because clinical CTC detection is extremely important, and POCT provides a reliable, simple, portable, fast, and low-cost method, we proposed possible implementation methods for POCT-based CTC detection in the following section. Firstly, integrating the CTC capture methods with POCT-based detection. Using CTC capture methods to separate and enrich the CTC in advance, including magnetic separation of CTC by antigen-based method, or enrichment of CTC by physical properties-based method, or capture and release of CTC by electrochemical method. And then introduce the enriched CTC into small chambers, add aptamer/antibody-microbeads (with catalytic properties) and add substrate, the microbeads can catalyze the reaction, induce color change, or generate gas, and by recording the color change/pressure change/pressure-driven distance, achieve the quantification of CTC. The key step is to select CTC specific aptamers, select microbeads with suitable enzyme catalytic activity and select suitable reaction substrates, which can eventually generate easy-to-detect signals. Secondly, simplify the separation and enrichment method as much as possible. For example, find ways to make magnetic separation smaller and easier to carry, use hand push instead of push pump, miniaturize the electrode and power supply. Finally, it is a very wise idea to combine smart phones with POCT, because mobile phones, as a portable tool, facilitate people to collect, process, and present results [144]. At present, people have tried various methods to use measurement function, camera function, and color analysis capabilities of the mobile 
phone, and have also developed various software to make the mobile phone suitable for POCT detection. Many studies have shown that bright-field detection, colorimetric detection, fluorescence detection, and electrochemical detection can be realized on mobile phones. The test samples also cover blood, tears, sweat, saliva, and urine, etc. For example, Knowlton et al. used a magnetic field to separate cells, and then used the camera of the mobile phone matched with appropriate optical components to perform brightfield and fluorescence imaging of the cells. The entire system is very small and does not require large magnetic separation device and fluorescence microscope, and the separation and quantification can be achieved by only a mobile phone and a few simple components [145].

Although the current electrochemical detection of CTC is less used in clinical practice, we believe that electrochemical method, as an effective and convenient method, has developed rapidly in recent years and can be used in clinical practice in the near future. At the same time, we believe that achieving POCT-based CTC detection through suitable integration is important. This is the development trend of CTC clinical testing and the future direction of testing.

Author Contributions: C.L.; wrote the paper, J.H.; reviewed the article and provided the feedback, X.S.; reviewed the article and provided the feedback, G.Y.; supervision. All authors have read and agreed to the published version of the manuscript.

Funding: This study was supported by the National Natural Science Foundation of China $(11875079,11434001$ and 119210067) and the National Grand Instrument Project (2019YFF01014400).

Acknowledgments: We are very grateful to Wenzong Ma for helpful discussions.

Conflicts of Interest: The authors declare no conflict of interest.

\section{Abbreviations}

The following abbreviations are used in this manuscript:

$\begin{array}{ll}\text { CTC } & \text { circulating tumor cell } \\ \text { ctDNA } & \text { circulating tumor DNA } \\ \text { EV } & \text { extracellular vesicle } \\ \text { WBC } & \text { white blood cell } \\ \text { RBC } & \text { red blood cell } \\ \text { EpCAM } & \text { epithelial cell adhesion molecule } \\ \text { CK } & \text { cytokeratin } \\ \text { POCT } & \text { point-of-care testing } \\ \text { EMT } & \text { epithelial-mesenchymal transition } \\ \text { MET } & \text { mesenchymal- epithelial transition } \\ \text { ISET } & \text { isolation by size of epithelial tumor cell } \\ \text { DLD } & \text { deterministic lateral displacement } \\ \text { ECL } & \text { electrochemiluminescence } \\ \text { PEC } & \text { photoelectrochemical } \\ \text { EIS } & \text { electrochemical impedance spectroscopy } \\ \text { LSV } & \text { linear sweep voltammetry } \\ \text { LOD } & \text { the limit of detection } \\ \text { MPA } & \text { mercaptopropionic acid } \\ \text { NP } & \text { nanoparticle } \\ \text { AuNS } & \text { Au nanostar } \\ \text { GC } & \text { glassy carbon } \\ \text { DPV } & \text { differential pulse voltammetry } \\ \text { RCA } & \text { rolling circle amplification } \\ \text { HRP } & \text { horseradish peroxidase } \\ \text { AuNP } & \text { Au nanoparticle } \\ \text { AB } & \text { acetylene black } \\ \text { HCNT } & \text { hexagonal carbon nitride tube } \\ \text { GS } & \text { graphene nanosheet } \\ \text { CV } & \text { cyclic voltammetry } \\ & \end{array}$




$\begin{array}{ll}\text { QD } & \text { quantum dot } \\ \text { PDMS } & \text { polydimethylsiloxane } \\ \text { AuNW } & \text { Au nanowire } \\ \text { DM } & \text { daunomycin } \\ \text { TS } & \text { telomerase primer } \\ \text { CD } & \text { carbon dot } \\ \text { MN } & \text { magnetic nanosphere } \\ \text { MB } & \text { magnetic bead } \\ \text { PtNP } & \text { Pt nanoparticle } \\ \text { ALP } & \text { alkaline phosphatase } \\ \text { FDG } & \text { di- } \beta \text {-D-pyridine galactoside } \\ \text { FMG } & \text { fluorescein monogalactoside } \\ \text { ET } & \text { electrophoresis titration } \\ \text { MRB } & \text { moving reaction boundary } \\ \text { CEACAM5 } & \text { carcinoembryonic antigen-related cell adhesion molecules } 5 \\ \text { RI } & \text { refractive index } \\ \text { ACNP } & \text { aptamer-conjugated nanoparticle } \\ \text { GO } & \text { graphene oxide } \\ \text { EGFR } & \text { epidermal growth factor receptor } \\ \text { PSMA } & \text { prostate specific membrane antigen }\end{array}$

\section{References}

1. Steeg, P.S. Targeting metastasis. Nat. Rev. Cancer 2016, 16, 201-218. [CrossRef]

2. Sleeman, J.; Steeg, P.S. Cancer metastasis as a therapeutic target. Eur. J. Cancer 2010, 46, 1177-1180. [CrossRef]

3. Vaidyanathan, R.; Soon, R.H.; Zhang, P.; Jiang, K.; Lim, C.T. Cancer diagnosis: From tumor to liquid biopsy and beyond. Lab Chip 2018, 19, 11-34. [CrossRef]

4. Tadimety, A.; Closson, A.; Li, C.; Yi, S.; Shen, T.; Zhang, J.X.J. Advances in liquid biopsy on-chip for cancer management: Technologies, biomarkers, and clinical analysis. Crit. Rev. Clin. Lab. Sci. 2018, 55, 140-162. [CrossRef] [PubMed]

5. Hayes, D.F.; Cristofanilli, M.; Budd, G.T.; Ellis, M.J.; Stopeck, A.; Miller, M.C.; Matera, J.; Allard, W.J.; Doyle, G.V.; Terstappen, L.W. Circulating tumor cells at each follow-up time point during therapy of metastatic breast cancer patients predict progression-free and overall survival. Clin. Cancer Res. 2006, 12, 4218-4224. [CrossRef] [PubMed]

6. Snow, A.; Chen, D.; Lang, J.E. The current status of the clinical utility of liquid biopsies in cancer. Expert Rev. Mol. Diagn. 2019, 19, 1031-1041. [CrossRef] [PubMed]

7. Tellez-Gabriel, M.; Heymann, M.F.; Heymann, D. Circulating Tumor Cells as a Tool for Assessing Tumor Heterogeneity. Theranostics 2019, 9, 4580-4594. [CrossRef]

8. O'Flaherty, J.D.; Gray, S.; Richard, D.; Fennell, D.; O'Leary, J.J.; Blackhall, F.H.; O'Byrne, K.J. Circulating tumour cells, their role in metastasis and their clinical utility in lung cancer. Lung Cancer 2012, 76, 19-25. [CrossRef]

9. Samlowski, W.E.; McGregor, J.R.; Samlowski, S.T.; Tharkar, S.; Shen, S.; Bentz, J.S. Growth of Circulating Tumor Cell-Derived Colonies from Peripheral Blood of Melanoma Patients: Preliminary Characterization of Colony Composition. Health 2014, 6, 1467-1481. [CrossRef]

10. Cheung, K.J.; Ewald, A.J. A collective route to metastasis: Seeding by tumor cell clusters. Science 2016, 352, 167-169. [CrossRef]

11. Wang, C.; Mu, Z.; Chervoneva, I.; Austin, L.; Ye, Z.; Rossi, G.; Palazzo, J.P.; Sun, C.; Abu-Khalaf, M.; Myers, R.E.; et al. Longitudinally collected CTCs and CTC-clusters and clinical outcomes of metastatic breast cancer. Breast Cancer Res. Treat. 2017, 161, 83-94. [CrossRef] [PubMed]

12. Khoo, B.L.; Grenci, G.; Lim, Y.B.; Lee, S.C.; Han, J.; Lim, C.T. Expansion of patient-derived circulating tumor cells from liquid biopsies using a CTC microfluidic culture device. Nat. Protoc. 2018, 13, 34-58. [CrossRef] [PubMed]

13. Yin, S.; Xi, R.; Wu, A.; Wang, S.; Li, Y.; Wang, C.; Tang, L.; Xia, Y.; Yang, D.; Li, J.; et al. Patient-derived tumor-like cell clusters for drug testing in cancer therapy. Sci. Transl. Med. 2020, 12. [CrossRef] [PubMed] 
14. Zhou, J.; Tu, C.; Liang, Y.; Huang, B.; Fang, Y.; Liang, X.; Ye, X. The label-free separation and culture of tumor cells in a microfluidic biochip. Analyst 2020, 145, 1706-1715. [CrossRef]

15. Cheng, Y.H.; Chen, Y.C.; Lin, E.; Brien, R.; Jung, S.; Chen, Y.T.; Lee, W.; Hao, Z.; Sahoo, S.; Min Kang, H.; et al. Hydro-Seq enables contamination-free high-throughput single-cell RNA-sequencing for circulating tumor cells. Nat. Commun. 2019, 10, 2163. [CrossRef]

16. Hou, H.W.; Warkiani, M.E.; Khoo, B.L.; Li, Z.R.; Soo, R.A.; Tan, D.S.; Lim, W.T.; Han, J.; Bhagat, A.A.; Lim, C.T. Isolation and retrieval of circulating tumor cells using centrifugal forces. Sci. Rep. 2013, 3, 1259. [CrossRef]

17. Alix-Panabieres, C.; Pantel, K. Challenges in circulating tumour cell research. Nat. Rev. Cancer 2014, 14, 623-631. [CrossRef]

18. Weissenstein, U.; Schumann, A.; Reif, M.; Link, S.; Toffol-Schmidt, U.D.; Heusser, P. Detection of circulating tumor cells in blood of metastatic breast cancer patients using a combination of cytokeratin and EpCAM antibodies. BMC Cancer 2012, 12, 206. [CrossRef]

19. Banko, P.; Lee, S.Y.; Nagygyorgy, V.; Zrinyi, M.; Chae, C.H.; Cho, D.H.; Telekes, A. Technologies for circulating tumor cell separation from whole blood. J. Hematol. Oncol. 2019, 12, 48. [CrossRef]

20. Lin, Z.; Luo, G.; Du, W.; Kong, T.; Liu, C.; Liu, Z. Recent Advances in Microfluidic Platforms Applied in Cancer Metastasis: Circulating Tumor Cells' (CTCs) Isolation and Tumor-On-A-Chip. Small 2020, 16, e1903899. [CrossRef] [PubMed]

21. Nasiri, R.; Shamloo, A.; Ahadian, S.; Amirifar, L.; Akbari, J.; Goudie, M.J.; Lee, K.; Ashammakhi, N.; Dokmeci, M.R.; Di Carlo, D.; et al. Microfluidic-Based Approaches in Targeted Cell/Particle Separation Based on Physical Properties: Fundamentals and Applications. Small 2020, 16, e2000171. [CrossRef] [PubMed]

22. Sun, D.; Lu, J.; Zhang, L.; Chen, Z. Aptamer-based electrochemical cytosensors for tumor cell detection in cancer diagnosis: A review. Anal. Chim. Acta 2019, 1082, 1-17. [CrossRef] [PubMed]

23. Tang, Z.; Huang, J.; He, H.; Ma, C.; Wang, K. Contributing to liquid biopsy: Optical and electrochemical methods in cancer biomarker analysis. Coord. Chem. Rev. 2020, 415. [CrossRef]

24. Nagrath, S.; Sequist, L.V.; Maheswaran, S.; Bell, D.W.; Irimia, D.; Ulkus, L.; Smith, M.R.; Kwak, E.L.; Digumarthy, S.; Muzikansky, A.; et al. Isolation of rare circulating tumour cells in cancer patients by microchip technology. Nature 2007, 450, 1235-1239. [CrossRef] [PubMed]

25. Stott, S.L.; Hsu, C.H.; Tsukrov, D.I.; Yu, M.; Miyamoto, D.T.; Waltman, B.A.; Rothenberg, S.M.; Shah, A.M.; Smas, M.E.; Korir, G.K.; et al. Isolation of circulating tumor cells using a microvortex-generating herringbone-chip. Proc. Natl. Acad. Sci. USA 2010, 107, 18392-18397. [CrossRef]

26. Sarioglu, A.F.; Aceto, N.; Kojic, N.; Donaldson, M.C.; Zeinali, M.; Hamza, B.; Engstrom, A.; Zhu, H.; Sundaresan, T.K.; Miyamoto, D.T.; et al. A microfluidic device for label-free, physical capture of circulating tumor cell clusters. Nat. Methods 2015, 12, 685-691. [CrossRef]

27. Zhang, W.; Chen, H.; Yang, M.; Liao, L. Electrochemical assay for detection of circulating tumor cells based on LiFePO4 as electrochemical probe. Mater. Lett. 2020, 276. [CrossRef]

28. Yang, J.; Li, X.; Jiang, B.; Yuan, R.; Xiang, Y. In Situ-Generated Multivalent Aptamer Network for Efficient Capture and Sensitive Electrochemical Detection of Circulating Tumor Cells in Whole Blood. Anal. Chem. 2020, 92, 7893-7899. [CrossRef]

29. Peng, Y.; Peng, Y.; Tang, S.; Shen, H.; Sheng, S.; Wang, Y.; Wang, T.; Cai, J.; Xie, G.; Feng, W. PdIrBP mesoporous nanospheres combined with superconductive carbon black for the electrochemical determination and collection of circulating tumor cells. Mikrochim. Acta 2020, 187, 216. [CrossRef]

30. Luo, J.; Liang, D.; Zhao, D.; Yang, M. Photoelectrochemical detection of circulating tumor cells based on aptamer conjugated Cu2O as signal probe. Biosens. Bioelectron. 2020, 151, 111976. [CrossRef]

31. Park, J.; Han, D.H.; Park, J.K. Towards practical sample preparation in point-of-care testing: User-friendly microfluidic devices. Lab Chip 2020, 20, 1191-1203. [CrossRef] [PubMed]

32. Liu, D.; Tian, T.; Chen, X.; Lei, Z.; Song, Y.; Shi, Y.; Ji, T.; Zhu, Z.; Yang, L.; Yang, C. Gas-generating reactions for point-of-care testing. Analyst 2018, 143, 1294-1304. [CrossRef] [PubMed]

33. Manz, A.; Graber, N.; Widmer, H.M. Miniaturized Total Chemical-Analysis Systems-A Novel Concept for Chemical Sensing. Sens. Actuator B Chem. 1990, 1, 244-248. [CrossRef]

34. Goetz, J.G. Metastases go with the flow. Science 2018, 362, 999-1000. [CrossRef] [PubMed]

35. Sakamoto, S.; Kyprianou, N. Targeting anoikis resistance in prostate cancer metastasis. Mol. Asp. Med. 2010, 31, 205-214. [CrossRef] 
36. Meng, S.; Tripathy, D.; Frenkel, E.P.; Shete, S.; Naftalis, E.Z.; Huth, J.F.; Beitsch, P.D.; Leitch, M.; Hoover, S.; Euhus, D.; et al. Circulating tumor cells in patients with breast cancer dormancy. Clin. Cancer Res. 2004, 10, 8152-8162. [CrossRef]

37. Yeung, K.T.; Yang, J. Epithelial-mesenchymal transition in tumor metastasis. Mol. Oncol. 2017, 11, 28-39. [CrossRef] [PubMed]

38. Zhao, S.; Yang, H.; Zhang, M.; Zhang, D.; Liu, Y.; Liu, Y.; Song, Y.; Zhang, X.; Li, H.; Ma, W.; et al. Circulating tumor cells (CTCs) detected by triple-marker EpCAM, CK19, and hMAM RT-PCR and their relation to clinical outcome in metastatic breast cancer patients. Cell Biochem. Biophys. 2013, 65, 263-273. [CrossRef]

39. Yoon, S.O.; Kim, Y.T.; Jung, K.C.; Jeon, Y.K.; Kim, B.H.; Kim, C.W. TTF-1 mRNA-positive circulating tumor cells in the peripheral blood predict poor prognosis in surgically resected non-small cell lung cancer patients. Lung Cancer 2011, 71, 209-216. [CrossRef]

40. Yu, M.; Bardia, A.; Wittner, B.S.; Stott, S.L.; Smas, M.E.; Ting, D.T.; Isakoff, S.J.; Ciciliano, J.C.; Wells, M.N.; Shah, A.M.; et al. Circulating breast tumor cells exhibit dynamic changes in epithelial and mesenchymal composition. Science 2013, 339, 580-584. [CrossRef]

41. Yates, D.R.; Roupret, M.; Drouin, S.J.; Comperat, E.; Ricci, S.; Lacave, R.; Sebe, P.; Cancel-Tassin, G.; Bitker, M.O.; Cussenot, O. Quantitative RT-PCR analysis of PSA and prostate-specific membrane antigen mRNA to detect circulating tumor cells improves recurrence-free survival nomogram prediction after radical prostatectomy. Prostate 2012, 72, 1382-1388. [CrossRef] [PubMed]

42. Shimada, R.; Iinuma, H.; Akahane, T.; Horiuchi, A.; Watanabe, T. Prognostic significance of CTCs and CSCs of tumor drainage vein blood in Dukes' stage B and C colorectal cancer patients. Oncol. Rep. 2012, 27, 947-953. [CrossRef]

43. Iinuma, H.; Watanabe, T.; Mimori, K.; Adachi, M.; Hayashi, N.; Tamura, J.; Matsuda, K.; Fukushima, R.; Okinaga, K.; Sasako, M.; et al. Clinical significance of circulating tumor cells, including cancer stem-like cells, in peripheral blood for recurrence and prognosis in patients with Dukes' stage B and C colorectal cancer. J. Clin. Oncol. 2011, 29, 1547-1555. [CrossRef]

44. Aktas, B.; Kasimir-Bauer, S.; Heubner, M.; Kimmig, R.; Wimberger, P. Molecular profiling and prognostic relevance of circulating tumor cells in the blood of ovarian cancer patients at primary diagnosis and after platinum-based chemotherapy. Int. J. Gynecol. Cancer 2011, 21, 822-830. [CrossRef] [PubMed]

45. He, S.; Li, P.; He, S.; Long, T.; Zhang, N.; Fang, J.; Yu, Z. Detection of circulating tumour cells with the CellSearch system in patients with advanced-stage head and neck cancer: Preliminary results. J. Laryngol. Otol. 2013, 127, 788-793. [CrossRef]

46. Miller, M.C.; Doyle, G.V.; Terstappen, L.W. Significance of Circulating Tumor Cells Detected by the CellSearch System in Patients with Metastatic Breast Colorectal and Prostate Cancer. J. Oncol. 2010, 2010, 617421. [CrossRef] [PubMed]

47. Tang, M.; Wen, C.Y.; Wu, L.L.; Hong, S.L.; Hu, J.; Xu, C.M.; Pang, D.W.; Zhang, Z.L. A chip assisted immunomagnetic separation system for the efficient capture and in situ identification of circulating tumor cells. Lab Chip 2016, 16, 1214-1223. [CrossRef]

48. Talasaz, A.H.; Powell, A.A.; Huber, D.E.; Berbee, J.G.; Roh, K.H.; Yu, W.; Xiao, W.; Davis, M.M.; Pease, R.F.; Mindrinos, M.N.; et al. Isolating highly enriched populations of circulating epithelial cells and other rare cells from blood using a magnetic sweeper device. Proc. Natl. Acad. Sci. USA 2009, 106, 3970-3975. [CrossRef]

49. Mishra, A.; Dubash, T.D.; Edd, J.F.; Jewett, M.K.; Garre, S.G.; Karabacak, N.M.; Rabe, D.C.; Mutlu, B.R.; Walsh, J.R.; Kapur, R.; et al. Ultrahigh-throughput magnetic sorting of large blood volumes for epitope-agnostic isolation of circulating tumor cells. Proc. Natl. Acad. Sci. USA 2020, 117, 16839-16847. [CrossRef]

50. Liu, H.; Sun, N.; Ding, P.; Chen, C.; Wu, Z.; Zhu, W.; Liu, L.; Wang, Z.; Pei, R. Fabrication of aptamer modified $\mathrm{TiO} 2$ nanofibers for specific capture of circulating tumor cells. Colloids Surf. B Biointerfaces 2020, 191, 110985. [CrossRef]

51. Lou, H.Y.; Zhao, W.; Hanson, L.; Zeng, C.; Cui, Y.; Cui, B. Dual-Functional Lipid Coating for the Nanopillar-Based Capture of Circulating Tumor Cells with High Purity and Efficiency. Langmuir 2017, 33, 1097-1104. [CrossRef]

52. Jolly, M.K. Implications of the Hybrid Epithelial/Mesenchymal Phenotype in Metastasis. Front. Oncol. 2015, 5. [CrossRef] 
53. Diepenbruck, M.; Christofori, G. Epithelial-mesenchymal transition (EMT) and metastasis: Yes, no, maybe? Curr. Opin. Cell Biol. 2016, 43, 7-13. [CrossRef]

54. Jiang, J.; Zhao, H.; Shu, W.; Tian, J.; Huang, Y.; Song, Y.; Wang, R.; Li, E.; Slamon, D.; Hou, D.; et al. An integrated microfluidic device for rapid and high-sensitivity analysis of circulating tumor cells. Sci. Rep. 2017, 7, 42612. [CrossRef]

55. Nanou, A.; Crespo, M.; Flohr, P.; De Bono, J.S.; Terstappen, L. Scanning Electron Microscopy of Circulating Tumor Cells and Tumor-Derived Extracellular Vesicles. Cancers 2018, 10, 416. [CrossRef]

56. Riethdorf, S.; Fritsche, H.; Muller, V.; Rau, T.; Schindlbeck, C.; Rack, B.; Janni, W.; Coith, C.; Beck, K.; Janicke, F.; et al. Detection of circulating tumor cells in peripheral blood of patients with metastatic breast cancer: A validation study of the CellSearch system. Clin. Cancer Res. 2007, 13, 920-928. [CrossRef]

57. Theil, G.; Fischer, K.; Weber, E.; Medek, R.; Hoda, R.; Lucke, K.; Fornara, P. The Use of a New CellCollector to Isolate Circulating Tumor Cells from the Blood of Patients with Different Stages of Prostate Cancer and Clinical Outcomes-A Proof-of-Concept Study. PLoS ONE 2016, 11, e0158354. [CrossRef] [PubMed]

58. Yoon, H.J.; Shanker, A.; Wang, Y.; Kozminsky, M.; Jin, Q.; Palanisamy, N.; Burness, M.L.; Azizi, E.; Simeone, D.M.; Wicha, M.S.; et al. Tunable Thermal-Sensitive Polymer-Graphene Oxide Composite for Efficient Capture and Release of Viable Circulating Tumor Cells. Adv. Mater. 2016, 28, 4891-4897. [CrossRef]

59. Loutherback, K.; D’Silva, J.; Liu, L.Y.; Wu, A.; Austin, R.H.; Sturm, J.C. Deterministic separation of cancer cells from blood at $10 \mathrm{~mL} / \mathrm{min}$. AIP Adv. 2012, 2. [CrossRef]

60. Sollier, E.; Go, D.E.; Che, J.; Gossett, D.R.; O’Byrne, S.; Weaver, W.M.; Kummer, N.; Rettig, M.; Goldman, J.; Nickols, N.; et al. Size-selective collection of circulating tumor cells using Vortex technology. Lab Chip 2014, 14, 63-77. [CrossRef]

61. Warkiani, M.E.; Khoo, B.L.; Tan, D.S.W.; Bhagat, A.A.S.; Lim, W.T.; Yap, Y.S.; Lee, S.C.; Soo, R.A.; Han, J.; Lim, C.T. An ultra-high-throughput spiral microfluidic biochip for the enrichment of circulating tumor cells. Analyst 2014, 139, 3245-3255. [CrossRef] [PubMed]

62. Lin, E.; Rivera-Báez, L.; Fouladdel, S.; Yoon, H.J.; Guthrie, S.; Wieger, J.; Deol, Y.; Keller, E.; Sahai, V.; Simeone, D.M.; et al. High-Throughput Microfluidic Labyrinth for the Label-free Isolation of Circulating Tumor Cells. Cell Syst. 2017, 5, 295-304.e4. [CrossRef] [PubMed]

63. Shen, S.; Tian, C.; Li, T.; Xu, J.; Chen, S.-W.; Tu, Q.; Yuan, M.-S.; Liu, W.; Wang, J. Spiral microchannel with ordered micro-obstacles for continuous and highly-efficient particle separation. Lab Chip 2017, 17, 3578-3591. [CrossRef]

64. Abdulla, A.; Liu, W.; Gholamipour-Shirazi, A.; Sun, J.; Ding, X. High-Throughput Isolation of Circulating Tumor Cells Using Cascaded Inertial Focusing Microfluidic Channel. Anal. Chem. 2018, 90, 4397-4405. [CrossRef]

65. Gao, R.; Cheng, L.; Wang, S.; Bi, X.; Wang, X.; Wang, R.; Chen, X.; Zha, Z.; Wang, F.; Xu, X.; et al. Efficient separation of tumor cells from untreated whole blood using a novel multistage hydrodynamic focusing microfluidics. Talanta 2020, 207, 120261. [CrossRef]

66. Hosokawa, M.; Hayata, T.; Fukuda, Y.; Arakaki, A.; Yoshino, T.; Tanaka, T.; Matsunaga, T. Size-Selective Microcavity Array for Rapid and Efficient Detection of Circulating Tumor Cells. Anal. Chem. 2010, 82, 6629-6635. [CrossRef] [PubMed]

67. Tang, Y.; Shi, J.; Li, S.; Wang, L.; Cayre, Y.E.; Chen, Y. Microfluidic device with integrated microfilter of conical-shaped holes for high efficiency and high purity capture of circulating tumor cells. Sci. Rep. 2014, 4. [CrossRef]

68. Park, E.S.; Jin, C.; Guo, Q.; Ang, R.R.; Duffy, S.P.; Matthews, K.; Azad, A.; Abdi, H.; Todenhöfer, T.; Bazov, J.; et al. Continuous Flow Deformability-Based Separation of Circulating Tumor Cells Using Microfluidic Ratchets. Small 2016, 12, 1909-1919. [CrossRef]

69. Hvichia, G.E.; Parveen, Z.; Wagner, C.; Janning, M.; Quidde, J.; Stein, A.; Muller, V.; Loges, S.; Neves, R.P.; Stoecklein, N.H.; et al. A novel microfluidic platform for size and deformability based separation and the subsequent molecular characterization of viable circulating tumor cells. Int. J. Cancer 2016, 138, 2894-2904. [CrossRef]

70. Hao, S.-J.; Wan, Y.; Xia, Y.-Q.; Zou, X.; Zheng, S.-Y. Size-based separation methods of circulating tumor cells. Adv. Drug Deliv. Rev. 2018, 125, 3-20. [CrossRef] 
71. Park, S.; Ang, R.R.; Duffy, S.P.; Bazov, J.; Chi, K.N.; Black, P.C.; Ma, H. Morphological differences between circulating tumor cells from prostate cancer patients and cultured prostate cancer cells. PLoS ONE 2014, 9, e85264. [CrossRef] [PubMed]

72. Hayashi, K.; Iwata, M. Stiffness of cancer cells measured with an AFM indentation method. J. Mech. Behav. Biomed. Mater. 2015, 49, 105-111. [CrossRef]

73. Wu, P.H.; Aroush, D.R.; Asnacios, A.; Chen, W.C.; Dokukin, M.E.; Doss, B.L.; Durand-Smet, P.; Ekpenyong, A.; Guck, J.; Guz, N.V.; et al. A comparison of methods to assess cell mechanical properties. Nat. Methods 2018, 15, 491-498. [CrossRef] [PubMed]

74. Sajeesh, P.; Raj, A.; Doble, M.; Sen, A.K. Characterization and sorting of cells based on stiffness contrast in a microfluidic channel. RSC Adv. 2016, 6, 74704-74714. [CrossRef]

75. Zahalak, G.I.; McConnaughey, W.B.; Elson, E.L. Determination of cellular mechanical properties by cell poking, with an application to leukocytes. J. Biomech. Eng. 1990, 112, 283-294. [CrossRef]

76. Zhou, Z.L.; Hui, T.H.; Tang, B.; Ngan, A.H.W. Accurate measurement of stiffness of leukemia cells and leukocytes using an optical trap by a rate-jump method. RSC Adv. 2014, 4. [CrossRef]

77. Raab, M.; Gentili, M.; de Belly, H.; Thiam, H.R.; Vargas, P.; Jimenez, A.J.; Lautenschlaeger, F.; Voituriez, R.; Lennon-Dumenil, A.M.; Manel, N.; et al. ESCRT III repairs nuclear envelope ruptures during cell migration to limit DNA damage and cell death. Science 2016, 352, 359-362. [CrossRef]

78. Zhou, M.D.; Hao, S.; Williams, A.J.; Harouaka, R.A.; Schrand, B.; Rawal, S.; Ao, Z.; Brenneman, R.; Gilboa, E.; Lu, B.; et al. Separable bilayer microfiltration device for viable label-free enrichment of circulating tumour cells. Sci. Rep. 2014, 4, 7392. [CrossRef]

79. Shim, J.-E.; Bu, J.; Lee, M.-K.; Cho, Y.-H.; Kim, T.-H.; Bu, J.-U.; Han, S.-W. Viable and high-throughput isolation of heterogeneous circulating tumor cells using tapered-slit filters. Sens. Actuators B Chem. 2020, 321. [CrossRef]

80. Farace, F.; Massard, C.; Vimond, N.; Drusch, F.; Jacques, N.; Billiot, F.; Laplanche, A.; Chauchereau, A.; Lacroix, L.; Planchard, D.; et al. A direct comparison of CellSearch and ISET for circulating tumour-cell detection in patients with metastatic carcinomas. Br. J. Cancer 2011, 105, 847-853. [CrossRef]

81. Rosenberg, R.; Gertler, R.; Friederichs, J.; Fuehrer, K.; Dahm, M.; Phelps, R.; Thorban, S.; Nekarda, H.; Siewert, J.R. Comparison of two density gradient centrifugation systems for the enrichment of disseminated tumor cells in blood. Cytometry 2002, 49, 150-158. [CrossRef] [PubMed]

82. Kulasinghe, A.; Kenny, L.; Perry, C.; Thiery, J.P.; Jovanovic, L.; Vela, I.; Nelson, C.; Punyadeera, C. Impact of label-free technologies in head and neck cancer circulating tumour cells. Oncotarget 2016, 7, 71223-71234. [CrossRef]

83. Yoon, Y.; Kim, S.; Lee, J.; Choi, J.; Kim, R.K.; Lee, S.J.; Sul, O.; Lee, S.B. Clogging-free microfluidics for continuous size-based separation of microparticles. Sci. Rep. 2016, 6, 26531. [CrossRef] [PubMed]

84. Liu, Z.; Huang, F.; Du, J.; Shu, W.; Feng, H.; Xu, X.; Chen, Y. Rapid isolation of cancer cells using microfluidic deterministic lateral displacement structure. Biomicrofluidics 2013, 7, 11801. [CrossRef]

85. Liu, Z.; Zhang, W.; Huang, F.; Feng, H.; Shu, W.; Xu, X.; Chen, Y. High throughput capture of circulating tumor cells using an integrated microfluidic system. Biosens. Bioelectron. 2013, 47, 113-119. [CrossRef] [PubMed]

86. Khoo, B.L.; Warkiani, M.E.; Tan, D.S.; Bhagat, A.A.; Irwin, D.; Lau, D.P.; Lim, A.S.; Lim, K.H.; Krisna, S.S.; Lim, W.T.; et al. Clinical validation of an ultra high-throughput spiral microfluidics for the detection and enrichment of viable circulating tumor cells. PLoS ONE 2014, 9, e99409. [CrossRef]

87. Boya, M.; Chu, C.H.; Liu, R.; Ozkaya-Ahmadov, T.; Sarioglu, A.F. Circulating Tumor Cell Enrichment Technologies. Recent Results Cancer Res. 2020, 215, 25-55. [CrossRef]

88. Wu, M.; Huang, P.H.; Zhang, R.; Mao, Z.; Chen, C.; Kemeny, G.; Li, P.; Lee, A.V.; Gyanchandani, R.; Armstrong, A.J.; et al. Circulating Tumor Cell Phenotyping via High-Throughput Acoustic Separation. Small 2018, 14, e1801131. [CrossRef]

89. Li, P.; Mao, Z.; Peng, Z.; Zhou, L.; Chen, Y.; Huang, P.H.; Truica, C.I.; Drabick, J.J.; El-Deiry, W.S.; Dao, M.; et al. Acoustic separation of circulating tumor cells. Proc. Natl. Acad. Sci. USA 2015, 112, 4970-4975. [CrossRef]

90. Zhang, Z.; Li, Q.; Du, X.; Liu, M. Application of electrochemical biosensors in tumor cell detection. Thorac. Cancer 2020, 11, 840-850. [CrossRef] 
91. Safarpour, H.; Dehghani, S.; Nosrati, R.; Zebardast, N.; Alibolandi, M.; Mokhtarzadeh, A.; Ramezani, M. Optical and electrochemical-based nano-aptasensing approaches for the detection of circulating tumor cells (CTCs). Biosens. Bioelectron. 2020, 148, 111833. [CrossRef] [PubMed]

92. Liu, P.; Wang, L.; Zhao, K.; Liu, Z.; Cao, H.; Ye, S.; Liang, G. High luminous efficiency Au@CDs for sensitive and label-free electrochemiluminescent detection of circulating tumor cells in serum. Sens. Actuators B Chem. 2020, 316. [CrossRef]

93. Li, J.; Lin, X.; Zhang, Z.; Tu, W.; Dai, Z. Red light-driven photoelectrochemical biosensing for ultrasensitive and scatheless assay of tumor cells based on hypotoxic AgInS2 nanoparticles. Biosens. Bioelectron. 2019, 126, 332-338. [CrossRef] [PubMed]

94. Tang, S.; Shen, H.; Hao, Y.; Huang, Z.; Tao, Y.; Peng, Y.; Guo, Y.; Xie, G.; Feng, W. A novel cytosensor based on Pt@Ag nanoflowers and AuNPs/Acetylene black for ultrasensitive and highly specific detection of Circulating Tumor Cells. Biosens. Bioelectron. 2018, 104, 72-78. [CrossRef]

95. Peng, Y.; Pan, Y.; Han, Y.; Sun, Z.; Jalalah, M.; Al-Assiri, M.S.; Harraz, F.A.; Yang, J.; Li, G. Direct Analysis of Rare Circulating Tumor Cells in Whole Blood Based on Their Controlled Capture and Release on Electrode Surface. Anal. Chem. 2020. [CrossRef]

96. Cao, H.-X.; Liu, P.-F.; Wang, L.; Liu, Z.-J.; Ye, S.-Y.; Liang, G.-X. Nonenzymatic chemiluminescence detection of circulating tumor cells in blood based on Au@luminol nanoparticles, hybridization chain reaction and magnetic isolation. Sens. Actuators B Chem. 2020, 318. [CrossRef]

97. Vajhadin, F.; Ahadian, S.; Travas-Sejdic, J.; Lee, J.; Mazloum-Ardakani, M.; Salvador, J.; Aninwene, G.E., 2nd; Bandaru, P.; Sun, W.; Khademhossieni, A. Electrochemical cytosensors for detection of breast cancer cells. Biosens. Bioelectron. 2020, 151, 111984. [CrossRef]

98. Dou, B.; Xu, L.; Jiang, B.; Yuan, R.; Xiang, Y. Aptamer-Functionalized and Gold Nanoparticle Array-Decorated Magnetic Graphene Nanosheets Enable Multiplexed and Sensitive Electrochemical Detection of Rare Circulating Tumor Cells in Whole Blood. Anal. Chem. 2019, 91, 10792-10799. [CrossRef]

99. Shen, C.; Liu, S.; Li, X.; Yang, M. Electrochemical Detection of Circulating Tumor Cells Based on DNA Generated Electrochemical Current and Rolling Circle Amplification. Anal. Chem. 2019, 91, 11614-11619. [CrossRef]

100. Figueiredo, J.; Lopes-Nunes, J.; Carvalho, J.; Antunes, F.; Ribeiro, M.; Campello, M.P.C.; Paulo, A.; Paiva, A.; Salgado, G.F.; Queiroz, J.A.; et al. AS1411 derivatives as carriers of G-quadruplex ligands for cervical cancer cells. Int. J. Pharm. 2019, 568. [CrossRef]

101. Hu, Y.; Duan, J.H.; Zhan, Q.M.; Wang, F.D.; Lu, X.; Yang, X.D. Novel MUC1 Aptamer Selectively Delivers Cytotoxic Agent to Cancer Cells In Vitro. PLoS ONE 2012, 7. [CrossRef] [PubMed]

102. Song, Y.L.; Zhu, Z.; An, Y.; Zhang, W.T.; Zhang, H.M.; Liu, D.; Yu, C.D.; Duan, W.; Yang, C.J. Selection of DNA Aptamers against Epithelial Cell Adhesion Molecule for Cancer Cell Imaging and Circulating Tumor Cell Capture. Anal. Chem. 2013, 85, 4141-4149. [CrossRef] [PubMed]

103. Zheng, T.; Zhang, Q.; Feng, S.; Zhu, J.J.; Wang, Q.; Wang, H. Robust nonenzymatic hybrid nanoelectrocatalysts for signal amplification toward ultrasensitive electrochemical cytosensing. J. Am. Chem. Soc. 2014, 136, 2288-2291. [CrossRef] [PubMed]

104. Huang, Y.F.; Shangguan, D.; Liu, H.; Phillips, J.A.; Zhang, X.; Chen, Y.; Tan, W. Molecular assembly of an aptamer-drug conjugate for targeted drug delivery to tumor cells. ChemBioChem 2009, 10, 862-868. [CrossRef]

105. Zheng, F.Y.; Cheng, Y.; Wang, J.; Lu, J.; Zhang, B.; Zhao, Y.J.; Gu, Z.Z. Aptamer-Functionalized Barcode Particles for the Capture and Detection of Multiple Types of Circulating Tumor Cells. Adv. Mater. 2014, 26, 7333-7338. [CrossRef]

106. Liu, G.D.; Mao, X.; Phillips, J.A.; Xu, H.; Tan, W.H.; Zeng, L.W. Aptamer-Nanoparticle Strip Biosensor for Sensitive Detection of Cancer Cells. Anal. Chem. 2009, 81, 10013-10018. [CrossRef]

107. Zeng, Z.; Tung, C.H.; Zu, Y. A cancer cell-activatable aptamer-reporter system for one-step assay of circulating tumor cells. Mol. Ther. Nucleic Acids 2014, 3, e184. [CrossRef]

108. Wan, Y.; Tan, J.F.; Asghar, W.; Kim, Y.T.; Liu, Y.L.; Iqbal, S.M. Velocity Effect on Aptamer-Based Circulating Tumor Cell Isolation in Microfluidic Devices. J. Phys. Chem. B 2011, 115, 13891-13896. [CrossRef]

109. Wan, Y.; Liu, Y.L.; Allen, P.B.; Asghar, W.; Mahmood, M.A.I.; Tan, J.F.; Duhon, H.; Kim, Y.T.; Ellington, A.D.; Iqbal, S.M. Capture, isolation and release of cancer cells with aptamer-functionalized glass bead array. Lab Chip 2012, 12, 4693-4701. [CrossRef] 
110. Shangguan, D.H.; Meng, L.; Cao, Z.H.C.; Xiao, Z.Y.; Fang, X.H.; Li, Y.; Cardona, D.; Witek, R.P.; Liu, C.; Tan, W.H. Identification of liver cancer-specific aptamers using whole live cells. Anal. Chem. 2008, 80, 721-728. [CrossRef]

111. Qu, L.; Xu, J.; Tan, X.; Liu, Z.; Xu, L.; Peng, R. Dual-aptamer modification generates a unique interface for highly sensitive and specific electrochemical detection of tumor cells. ACS Appl. Mater. Interfaces 2014, 6, 7309-7315. [CrossRef] [PubMed]

112. Frank, L.A.; Bashmakova, E.E.; Goncharova, N.S.; Krasitskaya, V.V. Bioluminescent Binding Microassay Using Aptamers as Biospecific Elements. J. Sib. Fed. Univ. Biol. 2019, 244-252. [CrossRef]

113. Bagalkot, V.; Farokhzad, O.C.; Langer, R.; Jon, S. An aptamer-doxorubicin physical conjugate as a novel targeted drug-delivery platform. Angew. Chem. Int. Ed. 2006, 45, 8149-8152. [CrossRef] [PubMed]

114. Min, K.; Song, K.M.; Cho, M.; Chun, Y.S.; Shim, Y.B.; Ku, J.K.; Ban, C. Simultaneous electrochemical detection of both PSMA (+) and PSMA (-) prostate cancer cells using an RNA/peptide dual-aptamer probe. Chem. Commun. 2010, 46, 5566-5568. [CrossRef] [PubMed]

115. Shen, H.; Yang, J.; Chen, Z.; Chen, X.; Wang, L.; Hu, J.; Ji, F.; Xie, G.; Feng, W. A novel label-free and reusable electrochemical cytosensor for highly sensitive detection and specific collection of CTCs. Biosens. Bioelectron. 2016, 81, 495-502. [CrossRef]

116. Cao, J.; Zhao, X.P.; Younis, M.R.; Li, Z.Q.; Xia, X.H.; Wang, C. Ultrasensitive Capture, Detection, and Release of Circulating Tumor Cells Using a Nanochannel-Ion Channel Hybrid Coupled with Electrochemical Detection Technique. Anal. Chem. 2017, 89, 10957-10964. [CrossRef]

117. Wang, S.S.; Zhao, X.P.; Liu, F.F.; Younis, M.R.; Xia, X.H.; Wang, C. Direct Plasmon-Enhanced Electrochemistry for Enabling Ultrasensitive and Label-Free Detection of Circulating Tumor Cells in Blood. Anal. Chem. 2019, 91, 4413-4420. [CrossRef]

118. Cordaro, A.; Neri, G.; Sciortino, M.T.; Scala, A.; Piperno, A. Graphene-Based Strategies in Liquid Biopsy and in Viral Diseases Diagnosis. Nanomaterials 2020, 10, 1014. [CrossRef]

119. Zhang, H.; Liang, F.; Wu, X.; Liu, Y.; Chen, A. Recognition and sensitive detection of CTCs using a controllable label-free electrochemical cytosensor. Mikrochim. Acta 2020, 187, 487. [CrossRef]

120. Bábelová, L.; Sohová, M.E.; Poturnayová, A.; Buríková, M.; Bizík, J.; Hianik, T. Label-free Electrochemical Aptasensor for Jurkat Cells Detection as a Potential Diagnostic Tool for Leukemia. Electroanalysis 2018, 30, 1487-1495. [CrossRef]

121. Du, X.; Zhang, Z.; Zheng, X.; Zhang, H.; Dong, D.; Zhang, Z.; Liu, M.; Zhou, J. An electrochemical biosensor for the detection of epithelial-mesenchymal transition. Nat. Commun. 2020, 11, 192. [CrossRef] [PubMed]

122. Zhou, X.; Li, Y.; Wu, H.; Huang, W.; Ju, H.; Ding, S. A amperometric immunosensor for sensitive detection of circulating tumor cells using a tyramide signal amplification-based signal enhancement system. Biosens. Bioelectron. 2019, 130, 88-94. [CrossRef] [PubMed]

123. Sun, D.; Lu, J.; Luo, Z.; Zhang, L.; Liu, P.; Chen, Z. Competitive electrochemical platform for ultrasensitive cytosensing of liver cancer cells by using nanotetrahedra structure with rolling circle amplification. Biosens. Bioelectron. 2018, 120, 8-14. [CrossRef] [PubMed]

124. An, L.; Wang, G.; Han, Y.; Li, T.; Jin, P.; Liu, S. Electrochemical biosensor for cancer cell detection based on a surface 3D micro-array. Lab Chip 2018, 18, 335-342. [CrossRef]

125. Yan, S.; Chen, P.; Zeng, X.; Zhang, X.; Li, Y.; Xia, Y.; Wang, J.; Dai, X.; Feng, X.; Du, W.; et al. Integrated Multifunctional Electrochemistry Microchip for Highly Efficient Capture, Release, Lysis, and Analysis of Circulating Tumor Cells. Anal. Chem. 2017, 89, 12039-12044. [CrossRef]

126. Zhai, T.T.; Ye, D.; Zhang, Q.W.; Wu, Z.Q.; Xia, X.H. Highly Efficient Capture and Electrochemical Release of Circulating Tumor Cells by Using Aptamers Modified Gold Nanowire Arrays. ACS Appl. Mater. Interfaces 2017, 9, 34706-34714. [CrossRef]

127. Zhang, Q.W.; Ouyang, J.; Wang, Y.; Zhai, T.T.; Wang, C.; Wu, Z.Q.; Zhang, T.Q.; Wang, K.; Xia, X.H. Specific cell capture and noninvasive release via moderate electrochemical oxidation of boronic ester linkage. Biosens. Bioelectron. 2019, 138, 111316. [CrossRef]

128. Gurudatt, N.G.; Chung, S.; Kim, J.M.; Kim, M.H.; Jung, D.K.; Han, J.Y.; Shim, Y.B. Separation detection of different circulating tumor cells in the blood using an electrochemical microfluidic channel modified with a lipid-bonded conducting polymer. Biosens. Bioelectron. 2019, 146, 111746. [CrossRef] 
129. Ferreira, C.E.S.; Guerra, J.C.C.; Slhessarenko, N.; Scartezini, M.; Franca, C.N.; Colombini, M.P.; Berlitz, F.; Machado, A.M.O.; Campana, G.A.; Faulhaber, A.C.L.; et al. Point-of-Care Testing: General Aspects. Clin. Lab 2018, 64, 1-9. [CrossRef]

130. Xu, L.; Wang, A.; Li, X.; Oh, K.W. Passive micropumping in microfluidics for point-of-care testing. Biomicrofluidics 2020, 14, 031503. [CrossRef]

131. Wang, J.; Li, D.; Qiu, Y.; Liu, X.; Huang, L.; Wen, H.; Hu, J. An europium functionalized carbon dot-based fluorescence test paper for visual and quantitative point-of-care testing of anthrax biomarker. Talanta 2020, 220, 121377. [CrossRef] [PubMed]

132. Cao, X.Y.; Kong, F.Z.; Zhang, Q.; Liu, W.W.; Liu, X.P.; Li, G.Q.; Zhong, R.; Fan, L.Y.; Xiao, H.; Cao, C.X. iPhone-imaged and cell-powered electrophoresis titration chip for the alkaline phosphatase assay in serum by the moving reaction boundary. Lab Chip 2018, 18, 1758-1766. [CrossRef]

133. Abate, M.F.; Jia, S.; Ahmed, M.G.; Li, X.; Lin, L.; Chen, X.; Zhu, Z.; Yang, C. Visual Quantitative Detection of Circulating Tumor Cells with Single-Cell Sensitivity Using a Portable Microfluidic Device. Small 2019, 15, e1804890. [CrossRef] [PubMed]

134. Wang, Y.; Yang, L.; Li, B.; Yang, C.J.; Jin, Y. Point-of-Care Assay of Telomerase Activity at Single-Cell Level via Gas Pressure Readout. Anal. Chem. 2017, 89, 8311-8318. [CrossRef]

135. Zhang, H.; Zhang, Z.; Wang, Y.; Wu, C.; Li, Q.; Tang, B. Rapid and Sensitive Detection of Cancer Cells Based on the Photothermal Effect of Graphene Functionalized Magnetic Microbeads. ACS Appl. Mater. Interfaces 2016, 8, 29933-29938. [CrossRef]

136. Ma, Y.; Mao, G.; Wu, G.; He, Z.; Huang, W. Magnetic bead-enzyme assemble for triple-parameter telomerase detection at single-cell level. Anal. Bioanal. Chem. 2020, 412, 5283-5289. [CrossRef]

137. Xiao, A.; Huang, Y.; Zheng, J.; Chen, P.; Guan, B.O. An Optical Microfiber Biosensor for CEACAM5 Detection in Serum: Sensitization by a Nanosphere Interface. ACS Appl. Mater. Interfaces 2020, 12, 1799-1805. [CrossRef] [PubMed]

138. Ainla, A.; Mousavi, M.P.S.; Tsaloglou, M.N.; Redston, J.; Bell, J.G.; Fernandez-Abedul, M.T.; Whitesides, G.M. Open-Source Potentiostat for Wireless Electrochemical Detection with Smartphones. Anal. Chem. 2018, 90, 6240-6246. [CrossRef]

139. Guo, J. Smartphone-Powered Electrochemical Dongle for Point-of-Care Monitoring of Blood beta-Ketone. Anal. Chem. 2017, 89, 8609-8613. [CrossRef]

140. Marrinucci, D.; Bethel, K.; Bruce, R.H.; Curry, D.N.; Hsieh, B.; Humphrey, M.; Krivacic, R.T.; Kroener, J.; Kroener, L.; Ladanyi, A.; et al. Case study of the morphologic variation of circulating tumor cells. Hum. Pathol. 2007, 38, 514-519. [CrossRef]

141. Keller, L.; Pantel, K. Unravelling tumour heterogeneity by single-cell profiling of circulating tumour cells. Nat. Rev. Cancer 2019, 19, 553-567. [CrossRef] [PubMed]

142. Yang, J.; Huang, X.; Gan, C.; Yuan, R.; Xiang, Y. Highly specific and sensitive point-of-care detection of rare circulating tumor cells in whole blood via a dual recognition strategy. Biosens. Bioelectron. 2019, 143. [CrossRef]

143. Xia, N.; Wu, D.; Yu, H.; Sun, W.; Yi, X.; Liu, L. Magnetic bead-based electrochemical and colorimetric assays of circulating tumor cells with boronic acid derivatives as the recognition elements and signal probes. Talanta 2020, 221. [CrossRef]

144. Liu, J.; Geng, Z.; Fan, Z.; Liu, J.; Chen, H. Point-of-care testing based on smartphone: The current state-of-the-art (2017-2018). Biosens. Bioelectron. 2019, 132, 17-37. [CrossRef] [PubMed]

145. Knowlton, S.; Joshi, A.; Syrrist, P.; Coskun, A.F.; Tasoglu, S. 3D-printed smartphone-based point of care tool for fluorescence- and magnetophoresis-based cytometry. Lab Chip 2017, 17, 2839-2851. [CrossRef]

Publisher's Note: MDPI stays neutral with regard to jurisdictional claims in published maps and institutional affiliations. 